\title{
Subsurface Stratigraphy and Petrophysical Analysis of the Middle Devonian Interval, Including the Marcellus Shale, of the Central Appalachian Basin; Northwestern Pennsylvania
}

\author{
Anne Yanni \\ West Virginia University
}

Follow this and additional works at: https://researchrepository.wvu.edu/etd

\author{
Recommended Citation \\ Yanni, Anne, "Subsurface Stratigraphy and Petrophysical Analysis of the Middle Devonian Interval, \\ Including the Marcellus Shale, of the Central Appalachian Basin; Northwestern Pennsylvania" (2010). \\ Graduate Theses, Dissertations, and Problem Reports. 3077. \\ https://researchrepository.wvu.edu/etd/3077
}

This Thesis is protected by copyright and/or related rights. It has been brought to you by the The Research Repository @ WVU with permission from the rights-holder(s). You are free to use this Thesis in any way that is permitted by the copyright and related rights legislation that applies to your use. For other uses you must obtain permission from the rights-holder(s) directly, unless additional rights are indicated by a Creative Commons license in the record and/ or on the work itself. This Thesis has been accepted for inclusion in WVU Graduate Theses, Dissertations, and Problem Reports collection by an authorized administrator of The Research Repository @ WVU. For more information, please contact researchrepository@mail.wvu.edu. 
Subsurface Stratigraphy and Petrophysical Analysis of the Middle Devonian Interval, Including the Marcellus Shale, of the Central Appalachian Basin; Northwestern Pennsylvania

\author{
Anne Yanni \\ Thesis submitted to the \\ College of Arts and Sciences \\ at West Virginia University \\ in partial fulfillment of the requirements \\ for the degree of \\ Master of Science \\ in \\ Geology
}

Dr. Timothy Carr, Ph.D., Chair

Dr. Dengliang Gao, Ph.D.

Dr. Jaime Toro, Ph.D.

Department of Geology and Geography

Morgantown, West Virginia

2010

Keywords: Marcellus Shale; Pennsylvania, Appalachian Basin; Middle Devonian; Marcellus Isopach; Marcellus Organic-Richness

Copyright 2010 Anne Yanni 


\begin{abstract}
Subsurface Stratigraphy and Petrophysical Analysis of the Middle Devonian Interval, Including the Marcellus Shale, of the Central Appalachian Basin; Northwestern Pennsylvania
\end{abstract}

Anne Yanni

In the central Appalachian basin, the multiple organic-rich intervals of the Middle Devonian, including the Marcellus Shale, are an emerging large resource play with high economic potential (estimated 1,307 trillion cubic feet of recoverable gas). This resource play was evaluated by examining the patterns of organic-richness, lithology, stratigraphic distribution, and other depositional characteristics. Using logs from wells throughout northwestern Pennsylvania (940 wells) integrated with core data, the subsurface lithostratigraphic boundaries were defined and correlated for the Marcellus and associated units throughout the study area.

Past studies of the Middle Devonian interval have not rigorously defined the lithostratigraphic boundaries in the subsurface and instead relied on limited petrophysical criteria (i.e. un-scaled gamma-ray). In this study, the interval was defined in the subsurface by using a multiple well log approach including the following curves: gammaray, bulk density, resistivity, photo electric, and neutron porosity.

Using previous studies on organic-rich Marcellus Shale, potential pay intervals were determined and mapped. The high amounts of total organic carbon (TOC) are correlated to more gas-rich intervals and vary significantly, both stratigraphically and spatially. A correlation was observed between uranium content derived from spectral gamma-ray logs and TOC. The relationship among gas content, TOC, and uranium in the Appalachian basin was evaluated using multiple petrophysical analyses techniques. The petrophysical results were used to improve regional and local understanding of the distribution and depositional controls on the Marcellus Shale. Numerous maps and cross sections were constructed to better display local and regional depositional patterns of Middle Devonian units across the central Appalachian basin including the Onondaga Limestone, Marcellus Shale, Mahantango Formation, Tully Limestone, and Genesee Formation.

In northwestern Pennsylvania, localized rapid changes in interpreted thick TOC accumulations are tied to local structures. The areas of highest TOC are identified by their relation to the underlying structure at the time of deposition and not by the gross unit thickness of the shale. The accumulation of thick organic-rich Marcellus Shale is interpreted as the interplay of decreased detrital input and increased organic production. These favorable areas appear to be closely related to favorable paleooceanographic conditions such as distance from sediment source and organic production related to paleotopography of the sea floor. These conditions define an exploration fairway through western Pennsylvania in terms of increased gas potential. 


\section{ACKNOWLEDGEMENTS}

I would like to thank National Energy Technology Laboratories for funding this research and for providing valuable core data. I would also like to thank Kristin Carter and Jaime Kostelnik from the Pennsylvania Department of Conservation and Natural Resources for their assistance with locating interpreted formation tops and vitrinite reflectance data.

I would like to thank my fellow Mountaineers for their constant support and encouragement: Dr. Timothy R. Carr, for accepting me as a student, providing financial assistance, and constantly and consistently guiding me throughout this entire project; Dr. Jaime Toro, for serving as both a professional and personal mentor throughout both my undergraduate and graduate degree programs; Dr. Dengliang Gao, for professional mentoring, supporting this project, and his personal introductions and resulting opportunities with international petroleum companies; and Dr. Matthew L. Boyce, for his constant help with this project and for generously sharing his time, data, skill, and knowledge.

I would also like to thank my family for their unconditional love and support, my new husband Rodney for his constant love and kindness, and my Great Uncle William Knight for his interest and encouragement. 


\section{TABLE OF CONTENTS}

TABLE OF CONTENTS .................................................................................... iv

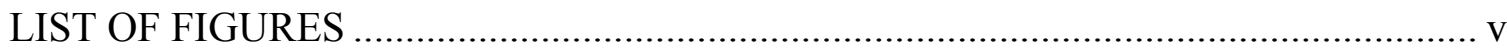

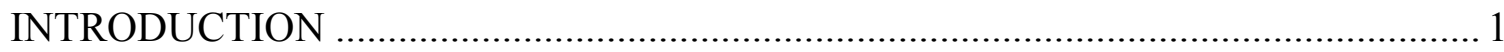

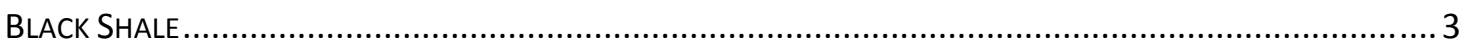

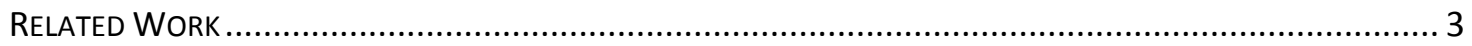

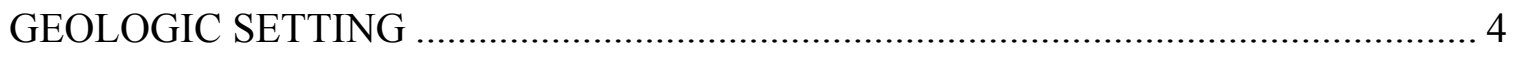

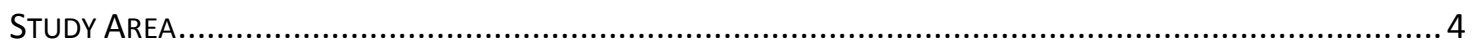

TECTONIC HISTORY, RegIONAL GEOLOGY, AND PALEOGEOGRAPHY .................................................... 5

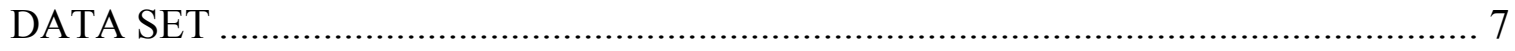

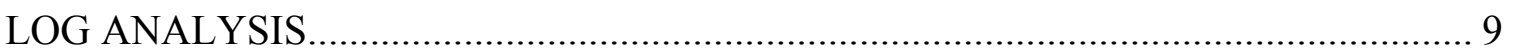

DEPOSITIONAL ENVIRONMENT AND LITHOSTRATIGRAPHY ........................ 10

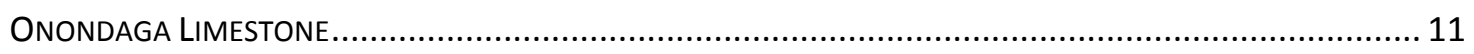

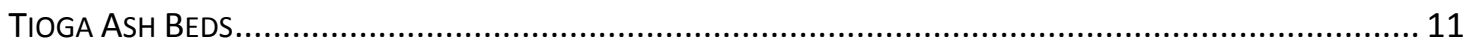

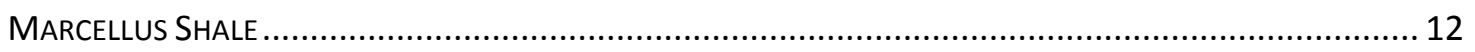

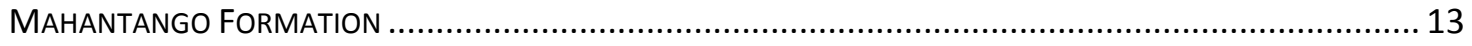

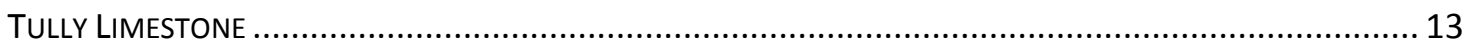

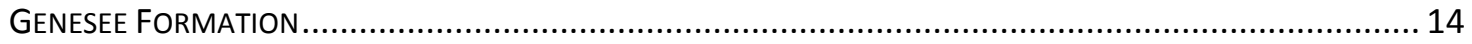

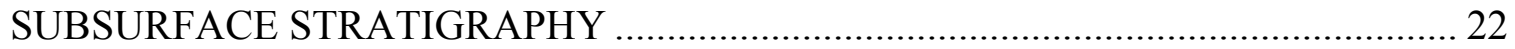

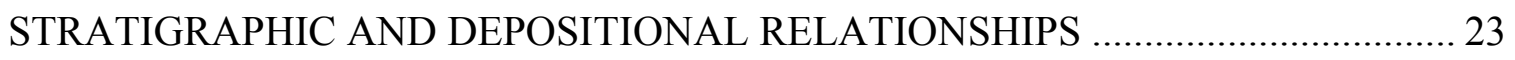

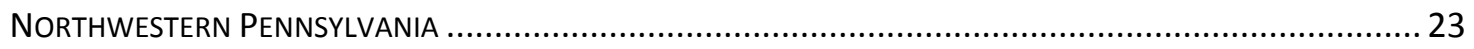

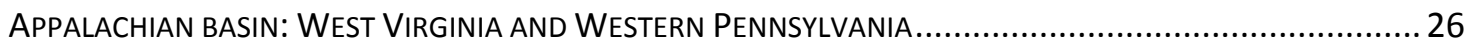

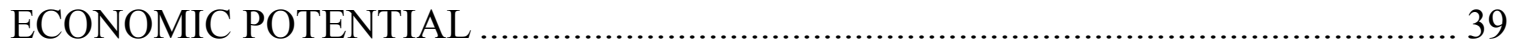

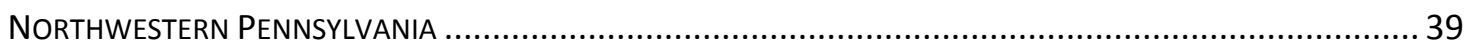

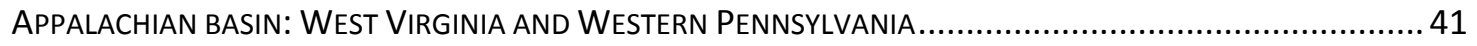

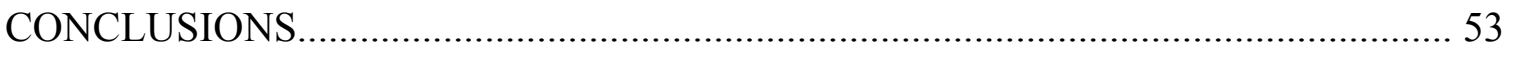

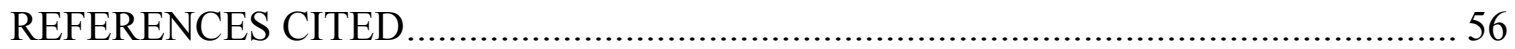




\section{LIST OF FIGURES}

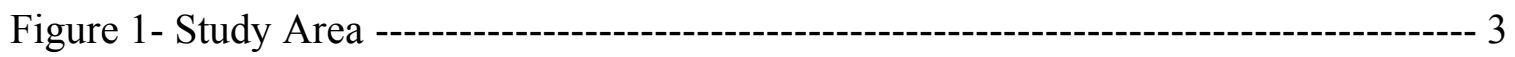

Figure 2- Paleogeographic Interpretation ----------------------------------------------------------- 5

Figure 3- Location of Core, Spectral Gamma-ray Logs and Type Logs ---------------------- 7

Figure 4- Relationship Between Standard Gamma-ray and Uranium Concentrations ---- 15

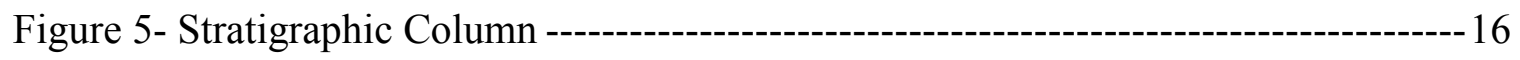

Figure 6- Type Log for West River, Tully, Mahantango, Marcellus and Onondaga Units

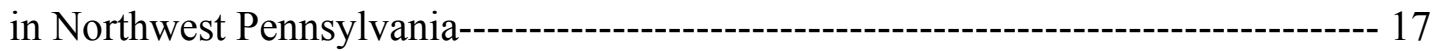

Figure 7- Type Log for West River, Penn Yan, Geneseo, Tully, Mahantango, and

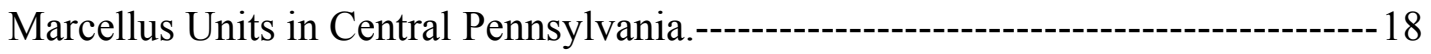

Figure 8- Northwest to Southeast Stratigraphic Cross Section---------------------------------19

Figure 9- Southwest to Northeast Stratigraphic Cross Section---------------------------------20

Figure 10- Onondaga Subsurface Structure ----------------------------------------------------- 26

Figure 11- Onondaga Limestone Isopach -------------------------------------------------------- 27

Figure 12-Marcellus Shale Isopach-----------------------------------------------------------------28

Figure 13- Mahantango Formation Isopach ---------------------------------------------------29

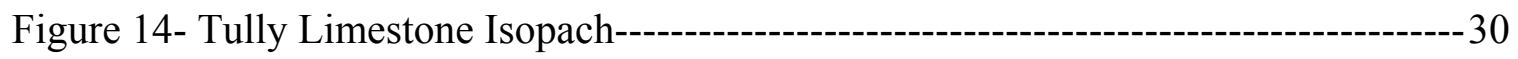

Figure 15- Genesee Formation Isopach ----------------------------------------------------------31

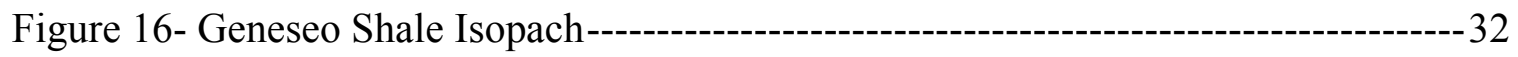

Figure 17- West River Isopach ---------------------------------------------------------------------33

Figure 18- Onondaga Limestone Isopach of West Virginia and Western Pennsylvania--34

Figure 19- Marcellus Shale Isopach of West Virginia and Western Pennsylvania --------35

Figure 20- Mahantango Isopach for West Virginia and Western Pennsylvania ------------36

Figure 21 - Tully Limestone Isopach of West Virginia and western Pennsylvania --------37

Figure 22- Marcellus Shale with Gamma-ray at 230 API -------------------------------------41

Figure 23- Net Thickness of Marcellus with Uranium Greater than 15 ppm-----------------42 
Figure 24- Marcellus Shale Interpreted Organic-richness at 7\% -----------------------------43

Figure 25- Genesee Formation with Gamma-ray at 230 API ----------------------------------44

Figure 26- Genesee Formation Interpreted Organic-Richness at 7\% -----------------------45

Figure 27- Geneseo Shale with Gamma-ray at 230 API ---------------------------------------46

Figure 28- Geneseo Shale Interpreted Organic-Richness at 7\% ------------------------------47

Figure 29- West River Shale with Gamma-ray at 230 API-----------------------------------48

Figure 30- West River Shale Interpreted Organic-Richness at 7\% ---------------------------49

Figure 31-Marcellus Shale Interpreted Organic-Richness at 7\% for West Virginia and Western Pennsylvania -----------------------------------------------------------------------50

Figure 32- Marcellus Shale Interpreted Organic-Richness at 7\% for West Virginia and Pennsylvania with Outline of Onondaga Limestone -------------------------------- 51 


\section{INTRODUCTION}

The Middle Devonian Marcellus Shale of northwestern Pennsylvania is an emerging unconventional shale gas play in the Appalachian basin. Historically, the petroleum production in this area was primarily from Upper Devonian sandstone units, while the Middle Devonian shale units were thought to have been the source. More recently, new stimulation techniques, such as hydraulic fracturing, have allowed production from the Middle Devonian Marcellus Shale unit; an organic-rich "black" shale that is extremely gas productive and widespread. Numerous estimates of the size of the Marcellus Shale play have been published. The Marcellus Shale unit underlies 34,000,000 acres of real estate (Engelder and Lash, 2008) and is estimated to contain 1,307 trillion cubic feet of recoverable gas $\left(37,511\right.$ billion $\left.\mathrm{m}^{3}\right)$ (Gold, 2008). In today's market, this estimate of recoverable gas is worth nearly $\$ 5.5$ trillion based on the Department of Energy's 8 September 2010 prices (U.S. EIA, 2010).

Because the Marcellus does not outcrop in northwestern Pennsylvania, subsurface data composes the entirety of information in this area. In northwestern Pennsylvania, only a small number of studies have been published for the Middle Devonian stratigraphy in the subsurface (Berg and others, 1986, and Rickard, 1975, and modified by Harper, 1999; Lash and Engelder, 2009). Also, petrophysical properties of the Middle Devonian in this area are not well documented.

The Middle Devonian stratigraphic succession of this area consists of the following formations in ascending order: Onondaga Limestone (Eifelian), Marcellus Shale (Eifelian), Mahantango Formation (Givetian), and the Tully Limestone (Givetian) (Berg, 1986; Rickard, 1975; and Harper, 1999). Additionally, the Tioga ash beds (Eifelian) 
separate the Marcellus Shale from the Onondaga Limestone (Onesquethawan and Cazenovian stages) (Berg, 1986; Rickard, 1975; and modified by Harper, 1999). Petrophysical criteria to define the stratigraphic intervals of the Middle Devonian used in the subsurface are unpublished creating ambiguity when determining unit boundaries. The Middle Devonian lithostratigraphic relationships in the subsurface in this area need to be documented in order to better understand the potential of the Marcellus Shale.

This study will provide an analysis of the subsurface relationships and petrophysics of the Middle Devonian interval in northwestern Pennsylvania, and produce a stratigraphic framework to better understand the distribution of the Marcellus Shale and related units. Additionally, lithologic and petrophysical criteria are established for evaluating the economic potential of unconventional resources for numerous intervals of the Middle Devonian.

Using wireline and geophysical logs from wells throughout the study area of western Pennsylvania (940 wells), the subsurface lithostratigraphic boundaries were defined and correlated for the Marcellus and associated units. Once the intervals were defined and correlated, this resource play was evaluated by examining the patterns of organicrichness, lithology, stratigraphic distribution, and other depositional characteristics. Mapping petrophysical data in northwestern Pennsylvania, such as total organic carbon (TOC) content and net feet of organic-rich shale, allows for a better understanding of the depositional history and economic potential of the Middle Devonian. 


\section{BLACK SHALE}

Shale is a very fine-grained, clastic sedimentary rock formed by the consolidation and compression of clay minerals and silt-sized particles of other minerals such as quartz and calcite. Shale is characterized by laminations. Coloration of shale is influenced by amount, type, and maturity of organic content (Arthur and Sageman, 1994). Black shale is named primarily for its organic matter content and results from the presence of carbonaceous material and indicates deposition under reducing conditions (Blatt and Tracy, 2000). The late Devonian to early Mississippian anoxic event is characterized by widespread, thick deposits of organic-rich black shale throughout the Appalachian basin.

\section{RELATED WORK}

Other studies at West Virginia University have concentrated on subsurface stratigraphy of the Middle Devonian Marcellus interval in southwestern Pennsylvania and West Virginia (Boyce and Carr, 2009). Boyce and Carr (2009) enhanced the understanding of the well log relationship to lithology and organic-richness, and created a depositional model of the Middle Devonian interval for southwestern Pennsylvania and West Virginia. Boyce and Carr (2009) relate the uranium concentration from the gamma-ray curve, and derived the TOC content from the uranium concentration discovering that an increase in uranium is associated with an increase in TOC. An increase in TOC is related to an increase in gas content thus providing a link between the uranium content and potential gas productivity (Boyce and Carr, 2009). Applying Boyce and Carr's findings and derivations to northwestern Pennsylvania allows for an improved examination of the Middle Devonian interval from West Virginia through western Pennsylvania. 


\section{GEOLOGIC SETTING}

\section{STUDY AREA}

The study area located in the central Appalachian basin encompasses a $14,175 \mathrm{mi}^{2}$ (36,

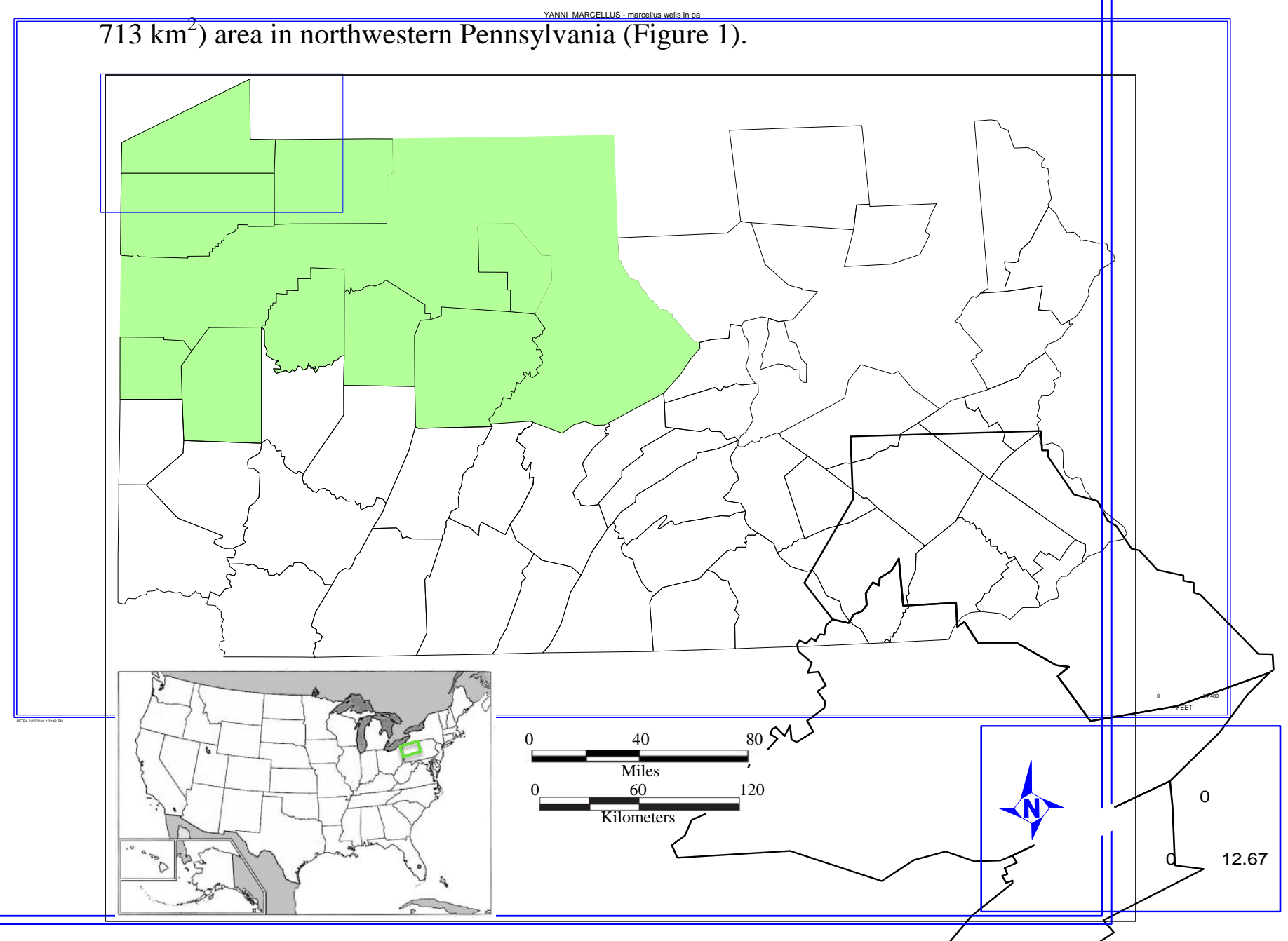

Figure 1- Study area is in northwestern Pennsylvania. It is located in the Appalachian geological province in the central Appalachian basin. 


\section{TECTONIC History, Regional GEOLOGY, AND PALEOGEOGRAPHY}

The Appalachian basin is a foreland basin. A foreland basin is a basin resting on continental lithosphere adjacent to a fold-thrust belt behind a continental margin arc, or a retro-arc foreland basin (Dickinson, 1974). A foreland basin is the result of overthrusting and folding. Subsidence occurs in the foreland due to elastic flexure. It is the flexural rigidity of the tectonic plate that transmits the stress due to the load to the foreland basin.

The Appalachian basin trends northeast to southwest and was developed during the Taconic orogeny, the second of four orogenies creating the Appalachian orogen during the Late Ordovician (Faill, 1997). The Taconic orogeny formed the Taconic highlands to the east creating a barrier for the Appalachian basin (Faill, 1997). The DevonianMississippian time was a period of global tectonism and the Middle Devonian records the beginning of the Acadian orogeny in the Appalachian basin and the ongoing assembly of Pangea (Ettensohn, 1994). During the Devonian-Mississippian, North America comprised the majority of the Laurasian continent (Ettensohn, 1998).

Following the Taconic orogeny is the Acadian orogeny (Middle Devonian). The Acadian orogeny involves the collision of Avalonian with Laurasian terranes (Ettensohn, 1987; Rast and Skehan, 1993). During the Acadian orogeny, paleoclimate and paleogeography (Ettensohn and Barron 1982; Ettensohn 1985) allowed for organic-rich black shale to dominate the initial stages of basin filling. It has been postulated that black shale deposition in the newly formed basins occurred when they were deepest, most restricted, and most sediment starved (Ettensohn, 1987). The restricted conditions indicated by 


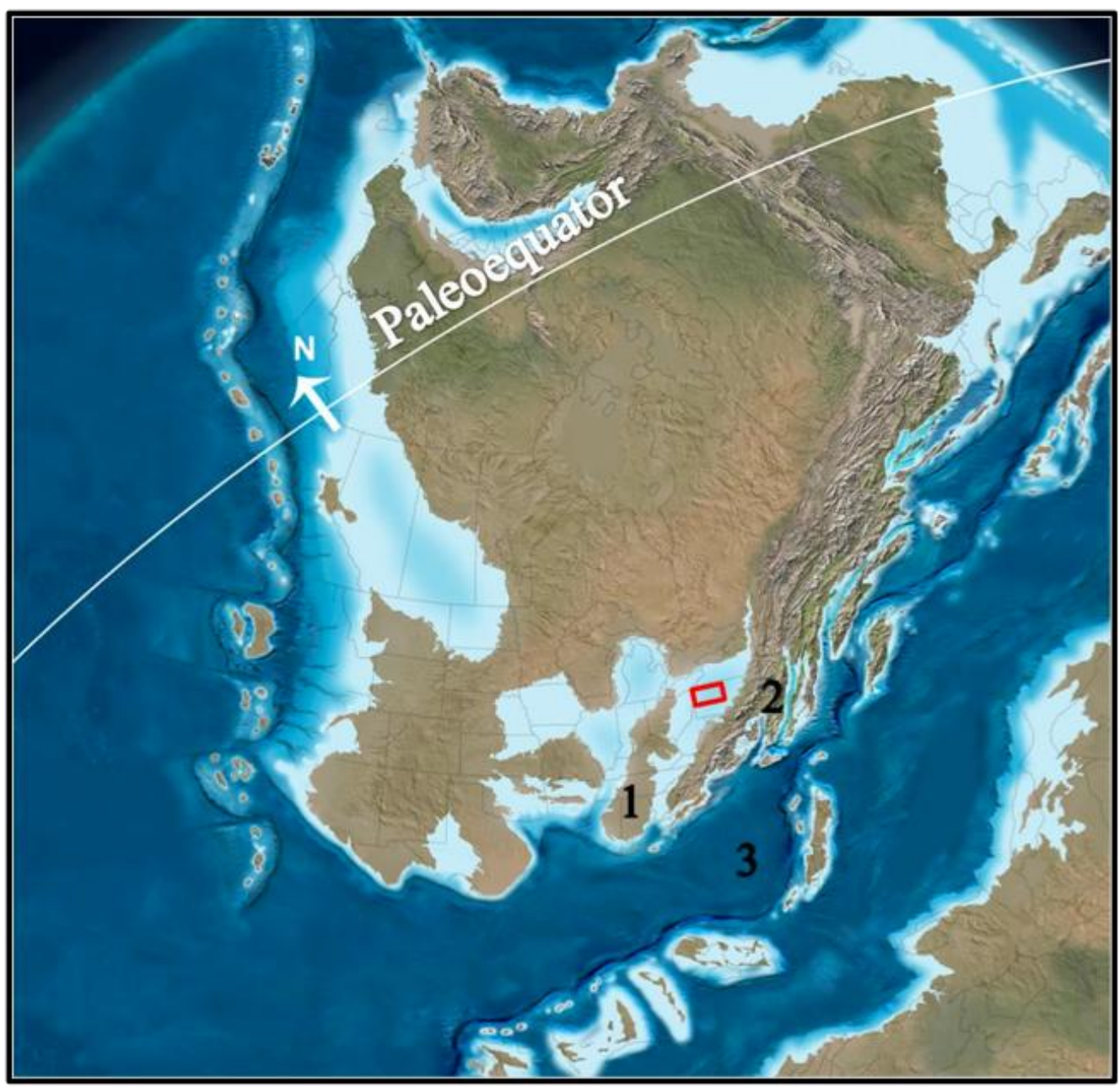

Figure 2- The study area is outlined in red on the paleogeographic interpretation of the Middle Devonian (385 Ma). Paleogeographic features surrounding the study area are as follows: 1) Cincinnati arch to the west, 2) Acadian mountains to the east, and the 3) Theic ocean to the south (Modified from Blakey, 2010).

the shale units may show the basin formed due to periods of sudden subsidence

(Ettensohn, 1987), but Schwietering (1981) suggests the basin was shallow during

deposition of shale and black shale deposition occurred in an epeiric sea environment where bottom waters were likely oxygen restricted.

During the Devonian, the Appalachian basin was in the southern hemisphere near the equator resulting in a hot climate with seasonally restricted rainfall (Woodrow and others, 1973). The surrounding paleogeographic features created a basin restricted by 1) the 
Cincinnati arch to the west, 2) the Acadian mountains to the east, and the 3) Theic ocean to the south (Figure 2). Devonian-Mississippian black shale units were deposited during a global episode of warmth, sea level rise, and increased tectonic activity (Fischer, 1984).

\section{DATA SET}

The data set for this study consists of three core reports from the Department of Energy (DOE) and 940 geophysical logs acquired from TGS-NOPEC Geophysical Company. Vitrinite reflectance $\left(\mathrm{R}_{\mathrm{o}}\right)$ data was obtained from the Pennsylvania Department of Conservation and Natural Resources (DCNR) as well as from the core data obtained from the DOE Natural Gas Program. The three core reports obtained from the DOE are for cores located on the perimeter of the study area in the following counties: McKean, Erie, and Lawrence (Figure 3). Geochemical data including vitrinite reflectance $\left(\mathrm{R}_{\mathrm{o}}\right)$ and TOC were incorporated into the data set. The logs are displayed as raster images. Electric logs were only available as raster images. The available well log curves are: gamma-ray, neutron porosity, bulk density, resistivity, conductivity, spectral gamma-ray suite, photo electric (PE), caliper, and spontaneous potential curves. Only two wells have spectral gamma-ray logs (Figure 3). Raster images (150) throughout the study area were manually digitized to Log ASCII Standard (LAS) enabling the logs for petrophysical analysis. 


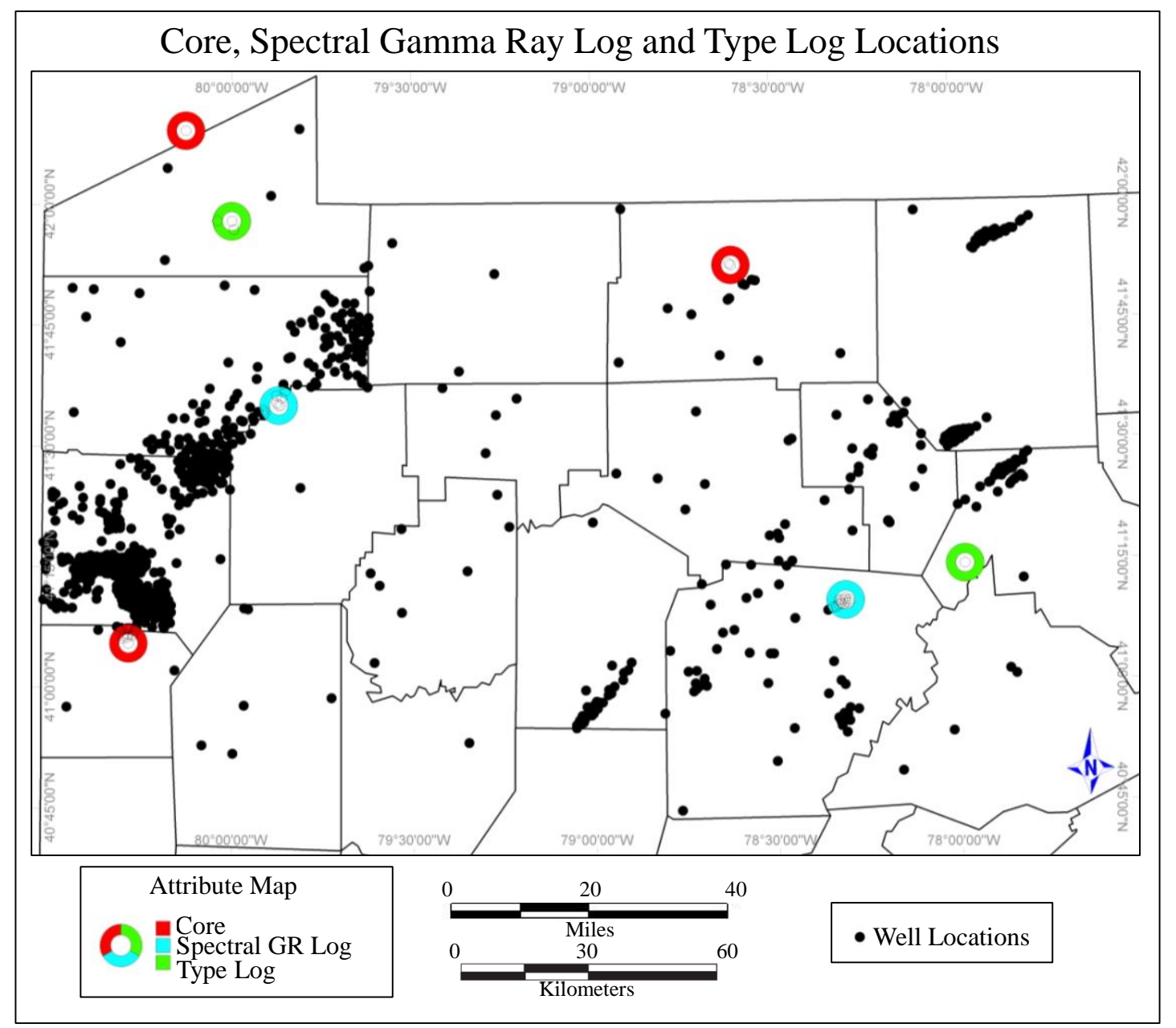

Figure 3- Core locations are highlighted in red, spectral gamma-ray logs are highlighted in blue, and type logs are highlighted in green.

\section{METHODOLOGY}

The primary method used in this investigation was correlating and analyzing wireline and geophysical logs. To begin identifying and correlating the Middle Devonian interval, two type logs were established for the study area, one in northwestern Pennsylvania and the other in central Pennsylvania (Figure 3). Once unit boundary characteristics were determined, cross-sections were correlated throughout the study area. The cross-sections provide the necessary data to create gridded surfaces used to generate subsurface maps across the study area. The grid size for northwestern Pennsylvania maps is two miles 
$(3.2 \mathrm{~km})$. The formation tops identified were used to create isopach maps for each interval using the gridding function in the IHS Petra $®$ map module. Some other key parameters were determined and mapped for the Middle Devonian units including structure, TOC content, and net feet of organic-rich shale. The isopach and petrophysical characteristic maps were used to better understand depositional history and resource potential.

\section{LOG ANALYSIS}

A combination of the gamma-ray, photoelectric index (PE), bulk density, and resistivity curves were used to determine formation boundaries. Net feet of organic-rich shale maps were generated and mapped in the study to better characterize resource potential using gamma-ray values above 230 API. Previous studies show a correlation between higher gamma-ray values and higher uranium to increased amounts of TOC in the Marcellus and related Middle Devonian units (Schmoker, 1981; Fertl and Rieke, 1980; Boyce and Carr, 2009). This relationship holds throughout northwestern Pennsylvania and provides a proxy to identify and quantify areas of increased TOC accumulation.

Uranium concentration was predicted using a polynomial from the spectral gamma-ray $\log$ to then extract uranium values from the standard gamma-ray log. In addition to the estimated uranium concentration, two spectral gamma-ray logs were available in the study area. The spectral gamma-ray logging tool measures thorium, uranium, and potassium. Uranium concentration derived from the spectral gamma-ray log plotted against the standard gamma-ray log show an increase in uranium can be predicted by an increase in the standard gamma-ray using a polynomial equation (Figure 4). Uranium concentrations can be calculated and extrapolated from the limited spectral logs using the 
abundant standard gamma-ray logs (Boyce, 2010). Since there are only two spectral gamma-ray logs for the study area, core and log data from Boyce's (2010) southwestern Pennsylvania and West Virginia study were incorporated. Boyce (2010) compared uranium core data to log data to calibrate the relationship between uranium and TOC in northwestern Pennsylvania. This relationship was logarithmic and when a log regression was used, a predicted TOC curve was created. The uranium/TOC curve was extrapolated throughout the study area showing interpreted organic-richness maps with a cutoff of $7 \%$ TOC. Higher uranium values provide a good measure of higher TOC and appear to be related to higher potential gas content (Boyce and Carr, 2009). When estimates are compared to actual TOC data, the error percentage for the organic-richness maps is approximately 20 percent.

\section{DEPOSITIONAL ENVIRONMENT AND LITHOSTRATIGRAPHY}

There are numerous rock types in the Devonian System in Pennsylvania. The Lower Devonian consists mostly of marine carbonate, chert, and shale; the Upper Devonian consists of marine to non-marine, coarse- to fine-grained terrigenous sediments; and the Middle Devonian rock types range from basinal marine shale to non-marine sandstone (Harper, 1999). The rock types in the study area are dominated by marine shale and limestone. The descriptions of units below apply to the study area ranging form the Middle Devonian Onondaga Limestone to the Upper Devonian Genesee Formation. A stratigraphic column (Figure 5) shows formations of interest. 


\section{ONONDAGA LIMESTONE}

In the subsurface of northwestern Pennsylvania, Fettke (1961) describes the Onondaga Limestone as a "very fine grained to crystalline, light to dark brownish gray, somewhat argillaceous and cherty limestone." The Onondaga Limestone is a light brown to gray to frosted, blocky, micaceous, very-fine, crystalline, very argillaceous in parts and a gray to dark-gray limey shale. In the subsurface, the Onondaga Limestone has a gamma-ray value of 30-110 API, a photo electric (PE) value of approximately 5 barns/electron, and a bulk density value of $2.71 \mathrm{~g} / \mathrm{cc}$ (Figures 6 and 7, Table 1). The subsurface Onondaga in New York and Pennsylvania is dominated by moderately deepwater carbonate facies that grade into the Marcellus Shale to the south (Kissling and Moshier, 1981). During deposition of the Onondaga Limestone, water depths increased as shown by a gradual northward shift of all carbonate facies of the Onondaga Limestone and by the Marcellus Shale northward migration with time (Kissling and Moshier, 1981). The transgressive Onondaga deposition ceased during basinwide stagnation of bottom waters and slow burial by the Marcellus Shale (Kissling and Moshier, 1981).

\section{TIOGA AsH BEDS}

The Tioga ash zone is a series of at least six layers of brown, yellowish-brown, or brownish-gray micaceous shale (Way and Smith, 1985) and contains up to 45 percent biotite (Roen and Hosterman, 1982). Roden and others (1990) used monzanite to date a sample from the Tioga ash bed of Pennsylvania near Lewisburg, Union County, Pennsylvania, to approximate the ash bed age at 388 million years old (Givetian). The ash beds are not continuous and can either appear in the Onondaga Limestone or the Marcellus Shale (Matt Boyce, Pers. Comm, 2010). Depending on location, the Marcellus 
Shale could contain no, few, or multiple ash beds. In northwest Pennsylvania, ash beds were not preserved. Variation in the presence and number of ash beds could indicate reworking by currents and/or bioturbation.

\section{MARCELluS SHALE}

The Marcellus Shale consists of dark-gray to black, highly fissile, homogenous, carbonaceous shale containing pyrite, iron bearing carbonated concretions, and shale brecciated beds (Harper, 1999). The Marcellus Shale is a predominately black to dark gray, sub-blocky to platy, moderately hard, brittle, carbonaceous, fissile, pyritic, and micaceous shale. The type area for the Marcellus Shale is in New York and the formation is located within the Hamilton Group (Linsley, 1976). X-ray diffraction results for a single core sample of Marcellus Shale south of this study area identify the following primary constituents of Marcellus Shale: 59\% quartz, 21\% illite, 2-8\% pyrite, and 2\% calcite, 5-20\% TOC (Matt Boyce, 2010). In the subsurface, the Marcellus Shale has gamma-ray values greater than 200 API and bulk density less than $2.55 \mathrm{~g} / \mathrm{cc}$ (Figures 6 and 7, Table 1).

The depositional environment of the Marcellus Shale is a source of debate. The Marcellus Shale in the Appalachian basin was deposited in a stratified water column under anerobic conditions. As long as there is a low level of circulation, water stratification is possible at different depths. Ettensohn (1998) suggests water stratification could have been caused by a rain shadow from the Acadian mountains to the east. Algeo and others (1998) suggest large vascular land plants enhanced chemical weathering through soil formation and were responsible for water stratification. Soil horizons weather causing an influx of organic matter into the basin elevating nutrient amounts. As 
larger root systems evolved, thicker soil horizons were created exposing more material to chemical weathering (Algeo and others, 1998). The Marcellus Shale also has been interpreted as deposited in a relatively shallow basin with water depth at approximately $230 \mathrm{ft}$ (70.1 m) (Schwietering, 1981) where anaerobic conditions were present allowing for large amounts of organic matter to be preserved.

\section{MAHANTANGO FORMATION}

The Mahantango Formation contains coarse-grained deposits from the clastic wedge created by the Acadian orogeny. Mahantango deposits are of shallow marine fossiliferous mudstone, sandstone, and quartz pebble conglomerate that are generally interpreted as coarsening upward cycles (Prave and Duke, 1991). Mahantango is interbedded siltstone, shale, and sandstone. In the subsurface, the Mahantango has a gamma-ray value below $200 \mathrm{API}$ and a bulk density value greater than $2.55 \mathrm{~g} / \mathrm{cc}$ (Figures 6 and 7, Table 1). In western Pennsylvania, the Mahantango Formation laterally grades into a finer grained, undifferentiated upper Hamilton Group (Harper and Piotrowski, 1979).

\section{TULLY LIMESTONE}

At the top of the Middle Devonian, the Tully Limestone is an olive to medium gray, fossiliferous shaly limestone or calcareous shale in outcrop (Faill and Wells, 1974). In the subsurface, the Tully Limestone is finely crystalline, brownish-gray, argillaceous limestone interbedded with dark gray calcareous shale (Fettke, 1961). The Tully Limestone is described as a dark-gray to gray, mica crystalline limestone that is moderately hard to hard, blocky, and with no visible porosity. In the subsurface, the Tully Limestone has a cleaner gamma-ray value of 30-110 API, a PE value of approximately 5 barns/electron and a bulk density value of 2.71 (Figures 6 and 7, Table 
1). The facies in the Tully represent relatively shallow water carbonate deposition under oxic conditions. The Tully Limestone was deposited on a carbonate ramp and is the last carbonate deposited in the basin until the late Devonian (Woodrow and others, 1988).

\section{GENESEE FORMATION}

At the base of the Upper Devonian, the Genesee Formation consists of dark-gray to black organic-rich fissile shale. In the subsurface, the Genesee Formation consists of dark-gray to black shale that is platy, moderately firm, silty, and sub-blocky with a moderate trace of calcite. The Genesee Formation in northwestern Pennsylvania is subdivided into three members: Geneseo Shale, Penn Yan Shale, and West River Shale.

The Geneseo Shale Member crops out in central and western New York and is composed of grayish-black, brownish-black, and black shale with some layers of siltstone and few beds of limestone (de Witt and others, 1993). In the subsurface, the Geneseo Shale Member is characterized as a gamma-ray of over 200 API and a bulk density less than $2.55 \mathrm{~g} / \mathrm{cc}$ (Figure 7, Table 1).

The Penn Yan Shale Member and the West River Shale Member consist of dark to medium gray shale and some beds of black shale, limestone nodules, and a few thick beds of dark gray siltstone (de Witt and others, 1993). In the study area, the Penn Yann Shale and West River Members have a bulk density below $2.55 \mathrm{~g} / \mathrm{cc}$ (Figure 7, Table 1). The Penn Yan has a gamma-ray of approximately 100 API, and is distinguishable from the West River Shale because the West River Shale has a gamma-ray value over 200 API (Figure 7, Table 1). 


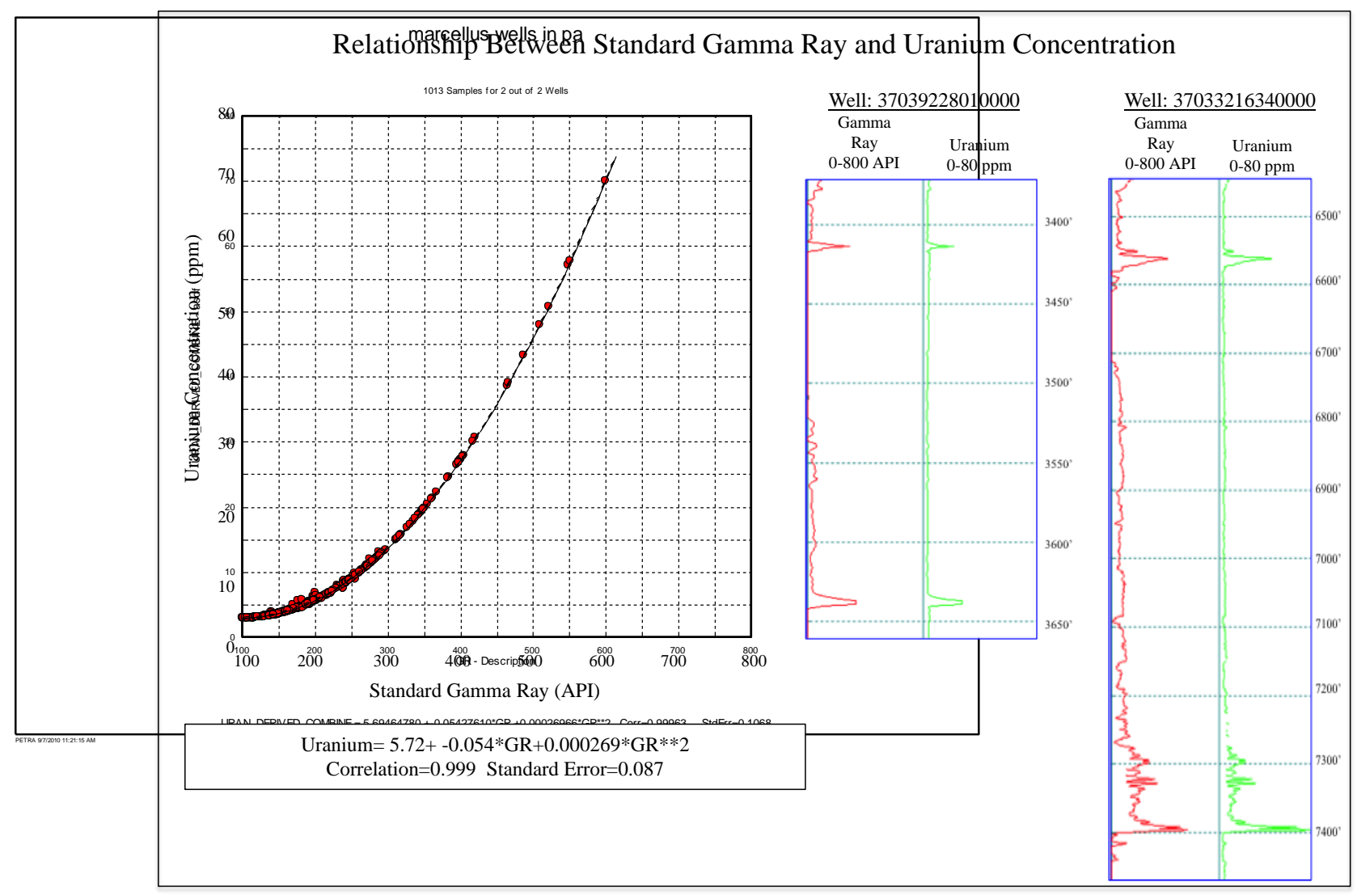

Figure 4- Relationship between standard gamma-ray and uranium concentrations from two spectral logs shows a polynomial equation. The depth intervals for each well are the depth intervals for the Marcellus Shale.

\begin{tabular}{|c|c|c|c|}
\hline \multicolumn{4}{|c|}{ Defining Characteristics } \\
\hline Stratigraphic Unit & Gamma Ray (API & PE Value (barns/cc) & Bulk Density (g/cc) \\
\hline Onondaga Limestone & $30-110$ & Approximately 5 & 2.71 \\
\hline Marcellus Shale & $>200$ & N/A & $<2.55$ \\
\hline Mahantango Fm & $<200$ & N/A & $>2.55$ \\
\hline Tully Limestone & $30-110$ & Approximately 5 & 2.71 \\
\hline Geneseo Shale & $>200$ & N/A & $<2.55$ \\
\hline Penn Yan Shale & Approximately 100 & N/A & $<2.55$ \\
\hline West River Shale & $>200$ & N/A & $<2.55$ \\
\hline
\end{tabular}

Table 1- Summary of defining characteristics used to determine the subsurface stratigraphic units in the study area. 


\begin{tabular}{|c|c|c|c|c|c|c|c|c|c|}
\hline & \multicolumn{3}{|c|}{$\begin{array}{l}\text { Northern West Virginia and } \\
\text { Southwestern Pennsylvania }\end{array}$} & \multicolumn{2}{|c|}{ Northwestern Pennsylvania } & \multicolumn{4}{|c|}{ Southern New York } \\
\hline Age & Forma & & Member & Formation & Member & & & Formation & Member \\
\hline \multirow{3}{*}{$\begin{array}{c}\text { Upper } \\
\text { Devonian }\end{array}$} & \multirow{3}{*}{\multicolumn{2}{|c|}{ Harrell Shale }} & & \multirow{3}{*}{ Genesee Formation } & West River Shale & \multirow{3}{*}{\multicolumn{3}{|c|}{ Genesee Shale }} & \\
\hline & & & & & Penn Yan Shale & & & & \\
\hline & & & & & Geneseo Shale & & & & \\
\hline \multirow{7}{*}{ 莺 } & \multicolumn{2}{|c|}{ Tully Limestone } & & Tully Limestone & & \multicolumn{3}{|c|}{ Tully Limestone } & \\
\hline & \multirow{3}{*}{\multicolumn{2}{|c|}{$\begin{array}{l}\text { Mahantango } \\
\text { Formation }\end{array}$}} & & \multirow{3}{*}{$\begin{array}{l}\text { Mahantango } \\
\text { Formation }\end{array}$} & & \multirow{6}{*}{ 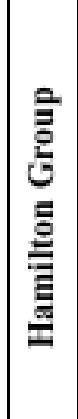 } & & Moscow Shale & \\
\hline & & & & & & & & Ludlowville & \\
\hline & & & & & & & & Skaneateles Shale & \\
\hline & \multirow{3}{*}{$\begin{array}{l}\text { Marcellus } \\
\text { Shale }\end{array}$} & Upper & \multirow{2}{*}{$\begin{array}{c}\text { Purcell } \\
\text { Limestone }\end{array}$} & \multirow{3}{*}{ Marcellus Shale } & & & \multirow{3}{*}{ 莺 } & Oatka Creek Shale & \multirow{3}{*}{$\begin{array}{l}\text { Cherry Valley } \\
\text { Limestone }\end{array}$} \\
\hline & & \multirow{2}{*}{ Lower } & & & & & & & \\
\hline & & & & & & & & Union Springs Shale & \\
\hline \multirow{4}{*}{$\frac{\bar{y}}{2}$} & \multicolumn{2}{|c|}{ Onondaga Limestone } & & Onondaga Limestone & & \multicolumn{3}{|c|}{ Onondaga Limestone } & \\
\hline & \multicolumn{2}{|c|}{ Huntersville Chert } & & Huntersville Chert & & & & & \\
\hline & \multicolumn{2}{|c|}{ Needmore Shale } & & Needmore Shale & & & & & \\
\hline & \multicolumn{2}{|c|}{ Oriskany Sandstone } & & Oriskany Sandstone & & \multicolumn{3}{|c|}{ Oriskany Sandstone } & \\
\hline
\end{tabular}

Figure 5- Stratigraphic colu mn for the study area compared to time equivalent units in northern West Virginia, southwestern Pennsylvania, and southern New York. The units for this study are in the column labeled Northwestern Pennsylvania. Compiled from Anderson and others (1984), de Witt and others (1993), Hasson and Dennison (1988), and Swezey (2002). 
Figure 6- Type log for West River, Tully, Mahantango, Marcellus, and Onondaga units in northwest Penns ylvania. The gammaray curve is plotted on Track 1 and ranges from 0-200 API. When the gamma-ray exceeds 200 API, it wraps around and is outlined in red. The bulk density is plotted in Track 2 and is shaded green for values less than $2.55 \mathrm{~g} / \mathrm{cc}$. The photo electric (PE) curve is plotted in Track 3 and ranges from $0-10$ barns/electron. The resistivity curve is plotted in Track 4 and is scaled from $0-100$ Oh ms. The warmer colors for the resistivity curve represent higher values and the colder colors represent lower values. 


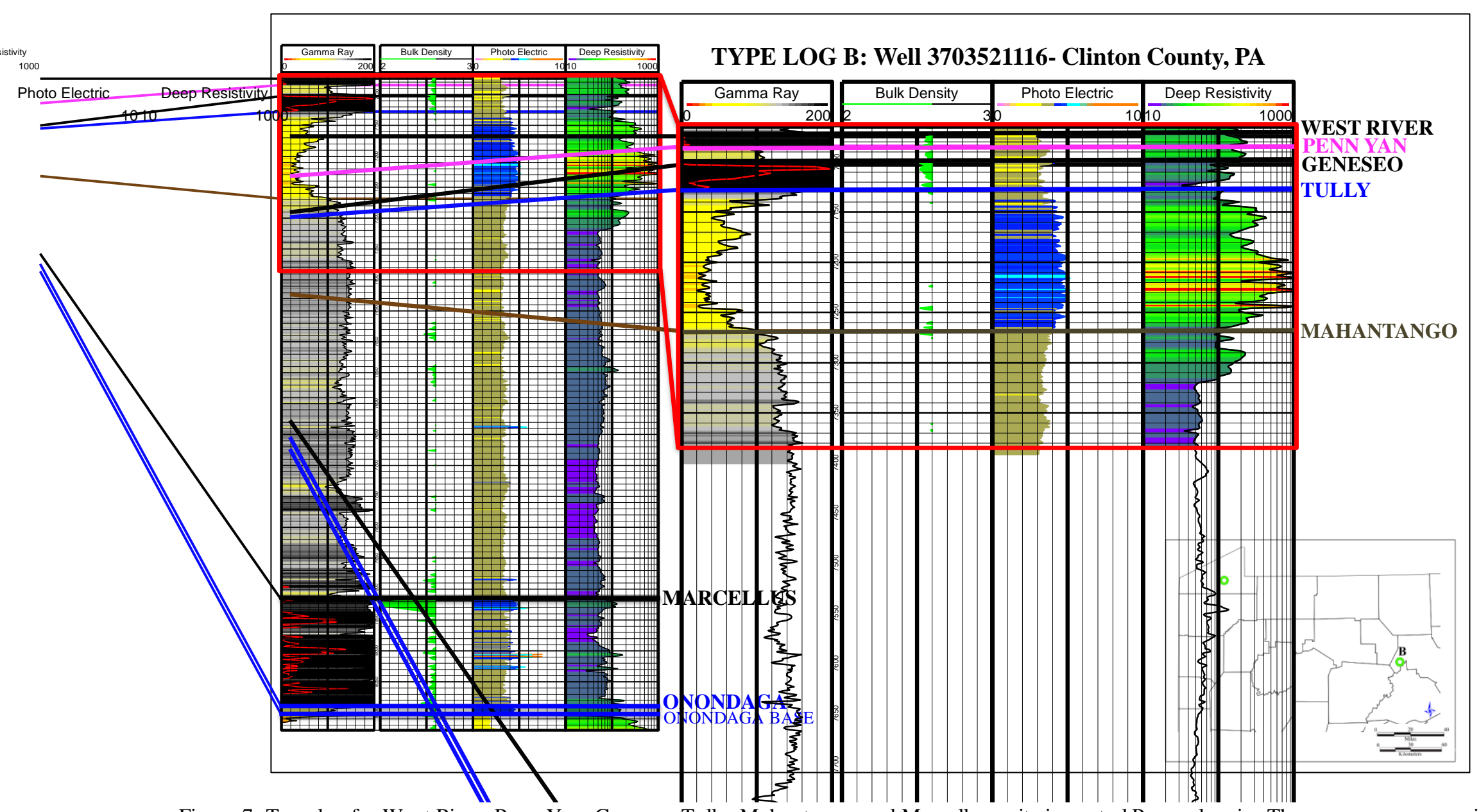

Figure 7- Type log for West River, Penn Yan, Geneseo, Tully, Mahantango, and Marcellus units in central Pennsylvania. The gamma-ray curve is plotted on Track 1 and ranges from 0-200 API. When the gamma-ray exceeds 200 API, it wraps around and is outlined in red. The bulk density is plotted in Track 2 and is shaded green for values less than $2.55 \mathrm{~g} / \mathrm{cc}$. The photo electric (PE) curve is plotted in Track 3 and ranges fro $\mathrm{m} 0-10 \mathrm{barns} / \mathrm{electron}$. The resistivity curve is plotted in Track 4 and is scaled fro $\mathrm{m} 0-100 \mathrm{Oh}$ ms. The warmer colors for the resistivity curve represent higher values and the colder colors represent lower values. 


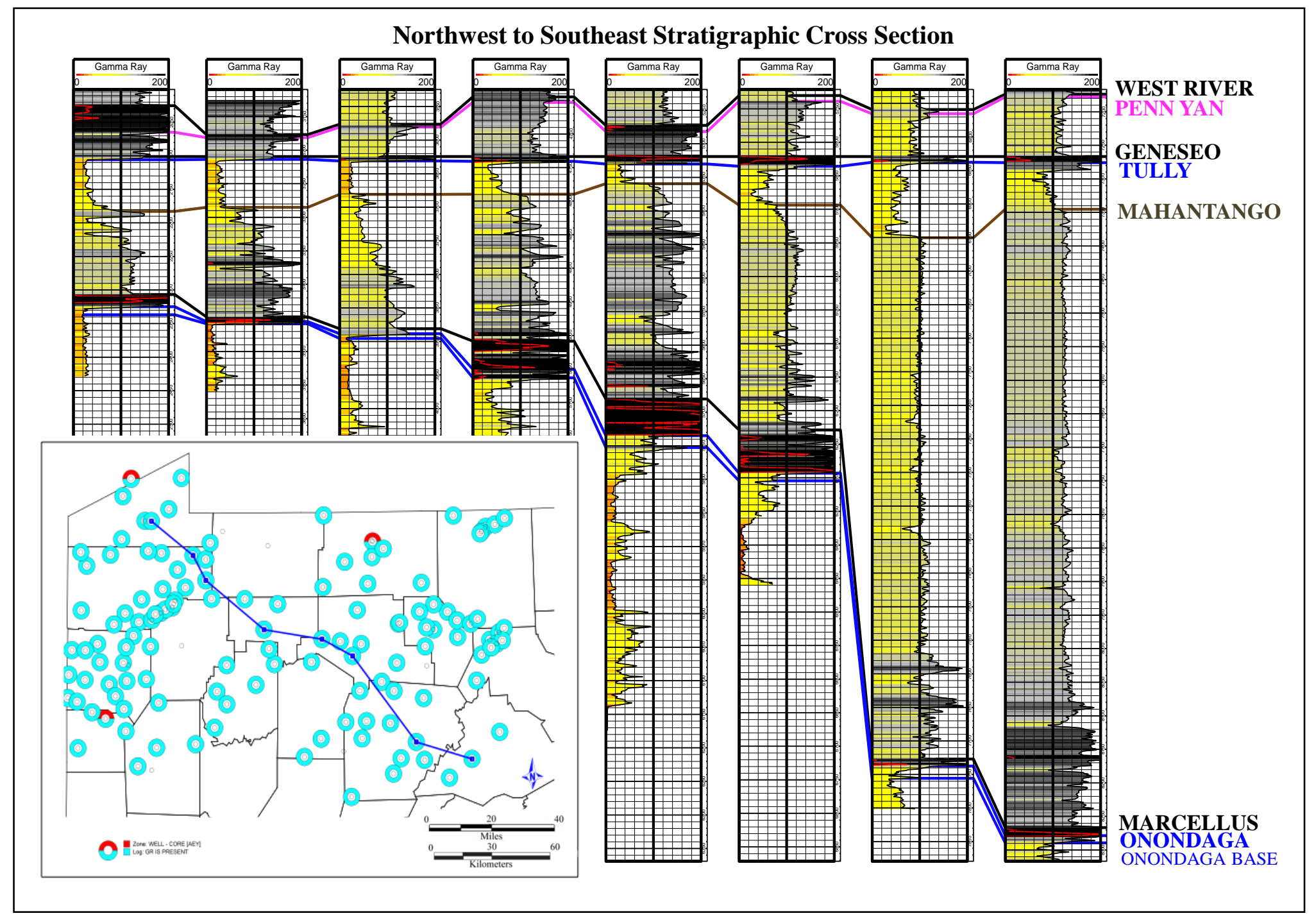

Figure $8=$ Northwest to southeast stratigraphic cross section hung on the Geneseo Shale Member. Observe the thinning of the Geneseo Sha le and the thickening of the West River Shale both to the northwest. 


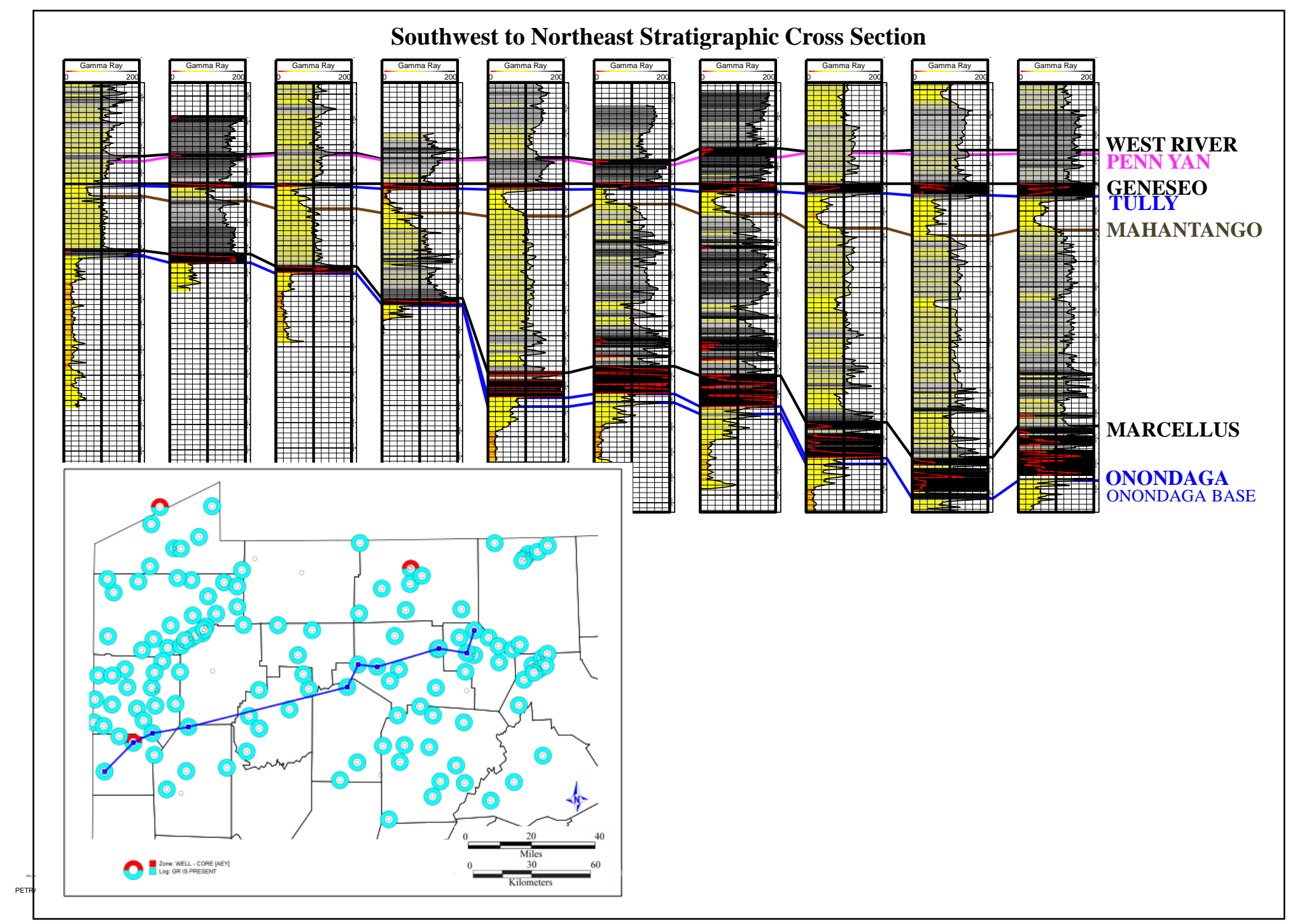

Figure 9- Southwest to northeast stratigraphic cross section hung on the Geneseo Shale Member. Observe the thickening of the Geneseo Shale towards the northeast. 
The units in this study were deposited in a stratified water column most likely created by the following conditions: 1) a large amount of organic matter, 2) low circulation, and 3) low sediment input (Demaison and Moore, 1980; Ettensohn and Barron, 1982). A stratified water column could also be created by high evaporation and/or temperature fluctuations at the surface. Because there are no salt deposits in the study area, stratification caused by evaporation is unlikely. Temperature fluctuations may have contributed to stratification. The stratified water column present during deposition of the units in this study had three zones controlled by levels of oxygen: oxic, sub-oxic, and anoxic zones. Each unit demonstrates the oxygen level. The Tully and Onondaga Limestone demonstrate deposition under oxic conditions. The Mahantango demonstrates deposition in the oxic to sub-oxic zones. The Marcellus Shale, Geneseo Shale, and West River Shale demonstrate deposition under anoxic conditions.

Organic matter enters the stratified water column and first is degraded in the oxic zone. The oxic zone contains aerobic bacteria that consume oxygen in the water column to break down organic matter. Although this is an efficient process of degradation, organic matter continues to sink into the sub-oxic zone. Due to low oxygen supply in the suboxic zone, anaerobic bacteria are forced to use nitrates as oxidants to degrade organic matter. Organic matter degradation by anaerobic bacteria, using nitrates as an oxidant, is a slower process and allows excess organic matter to sink into the anoxic zone. Since the oxygen and nitrates have been previously consumed in the oxic and sub-oxic zones, anaerobic bacteria in the anoxic zone are forced to use sulfates as an oxidant for degradation producing hydrogen sulfide (Demaison and Moore, 1980). The organic matter that reaches the sea floor accumulate and are preserved in the sediments. 


\section{SUBSURFACE STRATIGRAPHY}

In order to integrate the Middle Devonian in northwestern Pennsylvania with work in southwest Pennsylvania and West Virginia (Boyce, 2010; Boyce and Carr, 2009), several differences in subsurface stratigraphy from West Virginia, southwestern Pennsylvania, and northwestern Pennsylvania need to be discussed.

In southwestern Pennsylvania, the Harrell Shale is the black shale unit overlying the Tully Limestone (Boyce, 2010). In northwestern Pennsylvania, the Harrell Shale formally becomes the Genesee Formation. The Harrell Shale to the south is time equivalent to the Genesee Formation in northwest Pennsylvania. In northwestern Pennsylvania, the Genesee Formation is much more complex and consists of the Geneseo Shale, Penn Yan Shale, and the West River Shale. To the south, the Harrell Shale is not as complex. In southwestern Pennsylvania, the Burkett Shale is a formal member of the Harrell Shale. The Burkett Shale is time equivalent to the Geneseo Shale to the north. Two stratigraphic cross sections show the regional subsurface stratigraphy of the study area datumed on the Geneseo Shale Member of the Genesee Formation (Figures 8 and 9). The Geneseo Shale is present in the eastern section of the study area but laterally pinches out to the west. Also, the West River Shale is not always present. The West River Shale appears toward northwestern Pennsylvania. The base of the Onondaga Limestone is also very difficult to determine because available log suites were not always complete. The base of the Onondaga Limestone was not picked unless sufficient log curves were available to ensure a confident pick. 


\section{STRATIGRAPHIC AND DEPOSITIONAL RELATIONSHIPS}

\section{NORTHWESTERN PENNS YLVANIA}

Isopach and structure maps were constructed based on subsurface defined criteria and using log suites from 940 available wells. The structural trend in northwestern Pennsylvania is from northeast to southwest (Figure 10). The West Virginia Geological and Economic Survey (WVGES) publicly provides Ordovician fault data used as an overlay (WVGES, 2006). The Onondaga Limestone toward central Pennsylvania is 7,000 feet $(2,134 \mathrm{~m})$ subsea and 500 feet $(152 \mathrm{~m})$ subsea in northwestern Pennsylvania. The 6,500 feet variation from central to northwestern Pennsylvania reflects structure imposed by the various structure movements that formed the Appalachian basin. The small, localized structures may be the reactivation of structures or small, localized salt structures (Harrison and others, 2004). Isopach maps follow the broad regional structure of the area.

The Onondaga Limestone isopach shows a decrease in thickness from over 28 feet $(8.5$ $\mathrm{m})$ near central Pennsylvania to about a foot $(.3 \mathrm{~m})$ towards western Pennsylvania (Figure 11). The thickness trend in the Onondaga defines a shelf-like topographic high enhancing limestone accumulation (Boyce, 2010) and is related to local tectonics. The structural lows in the area affected the thickness of the Onondaga Limestone. A number of lows in the Onondaga Limestone structure (Figure 10) are related to localized areas of thinner Onondaga Limestone (Figure 11). There are numerous thinner areas in the Onondaga Limestone that may reflect smaller local structures.

In the study area, the Marcellus Shale shows a decrease in thickness from over 140 feet $(42.7 \mathrm{~m})$ in the southeast to less than a foot $(.3 \mathrm{~m})$ in the northwest (Figure 12). The 
majority of the decrease in thickness is along a northeast southwest trend (Figure 12). The Marcellus Shale is thicker to the southeast and thins to the northwest. There is a gradual change in thickness toward the northwest before there is a distinct drop off in thickness. The Marcellus Shale has the same local structures affected by the underlying Onondaga Limestone. Local structures in the Onondaga Limestone affect the thickness of the Marcellus Shale. The contact between the Marcellus Shale and Mahantango Formation is gradational (Figures 6 and 7).

An isopach map of the Mahantango Formation shows a decrease in thickness from over 775 feet $(236.2 \mathrm{~m})$ in the southeast of the study area to less than 75 feet $(22.9 \mathrm{~m})$ in the northwest (Figure 13). Depositionally, the Mahantango in northwest Pennsylvania is more complex than it is to the east and in central Pennsylvania. The Mahantango is composed of multiple lithologies with numerous sedimentary structures (Duke, Prave, and others, 1991). The northeast-southwest thickness trend observed in the Mahantango Formation (Figure 13) is similar to the trend observed in the Marcellus Shale, but the trend for the gradual thinning of the Mahantango is steeper. The Mahantango does not have the localized thicks and thins. It appears that the Marcellus Shale filled in the lows of the Onondaga Limestone creating a smooth area on which the Mahantango was deposited. The contact between the Mahantango Formation and Tully Limestone is gradational.

An isopach of the Tully Limestone shows a decrease in thickness from over 140 feet $(42.7 \mathrm{~m})$ to the southeast of the study area to less than 5 feet $(1.5 \mathrm{~m})$ to the west (Figure 14). The Tully Limestone wraps around the thickest portions of the Mahantango Formation in the southeast (Trend A, Figure 14). There is also a thick section of Tully 
Limestone to the northwest (Trend B, Figure 14). Additionally, there is a low area between the two thick sections of Tully. The thin Tully in the middle could be due to underlying structure. The contact between the Tully Limestone and Genesee Formation is gradational.

An isopach of the Genesee Formation shows a decrease in thickness from over 180 feet $(54.8 \mathrm{~m})$ to less than 10 feet $(3 \mathrm{~m})$. In the Genesee Formation, a thickness trend (A) is observed along faults (Figure 15). The Genes see Formation and the Marcellus Shale have similar thickness trends and defining characteristics (Table 1) suggesting the depositional environments are similar. Thicker Genesee Formation may be related to continued salt tectonics or thinner areas in the underlying Tully Limestone. The thin middle portion of the Tully Limestone (Figure 14) strongly correlates to the thickness trend (A) observed in the Genesee Formation. Additionally, the thickness trend (A) correlates with previous defined fault trends and the thick areas to the southeast also correlate to faulting.

An isopach of the Geneseo Shale shows a decrease in thickness from over 25 feet $(7.6 \mathrm{~m})$ to the northeast to less than a foot $(.3 \mathrm{~m})$ to the west. The thickness trend observed in the Geneseo Shale differs from the trends of the underlying units (Figure 16). The Geneseo Shale thickens to the northeast and thins to the southwest.

An isopach of the West River Shale shows a decrease in thickness from over 28 feet $(8.5$ $\mathrm{m})$ in the northwest to less than a foot $(.3 \mathrm{~m})$. West River Shale distribution does not follow any previously observed trends. The distribution of West River Shale occurs in pockets to the east and is not controlled by regional faulting (Figure 17). The West River 
Shale could be sourced from an area to the northwest. Another possibility for this change in distribution could be the center of subsidence shifting toward the west.

\section{APPALACHIAN BASIN: WeSt VIRGINIA AND WeSTERN PENNS YLVANIA}

A regional look at the Appalachian basin was created by combining wells from West Virginia and southwestern Pennsylvania (Boyce, 2010) with this study. Isopach maps were created for West Virginia and western Pennsylvania to show regional relationships. The thickest portions of the Onondaga Limestone isopach (Figure 18) resemble a shelflike feature in southwest Pennsylvania and eastern West Virginia. Limestone production rapidly decreases to the west creating a sharp break in limestone thickness. The Marcellus Shale (Figure 19) has an area of relatively thick deposits indicating increased detrital input. Maximum detrital input is shown in southwest Pennsylvania (Figure 19). Locally, the thickest portions of Marcellus Shale are in basin lows. The Mahantango Formation (Figure 20) is a thick wedge sourced from the east and northeast. The Mahantango is a thick clastic deposit forming a shelf-like feature in southwest Pennsylvania and northeast West Virginia and severs as a control for the deposition of the Tully Limestone. The Tully Limestone was produced off a positive feature and wraps around the thickest shelflike portions of the Mahantango Formation (Figure 21). Additionally, there is a low area between the two thick sections of Tully. This high-low-high relationship seen in the Tully could be due to underlying structure. 


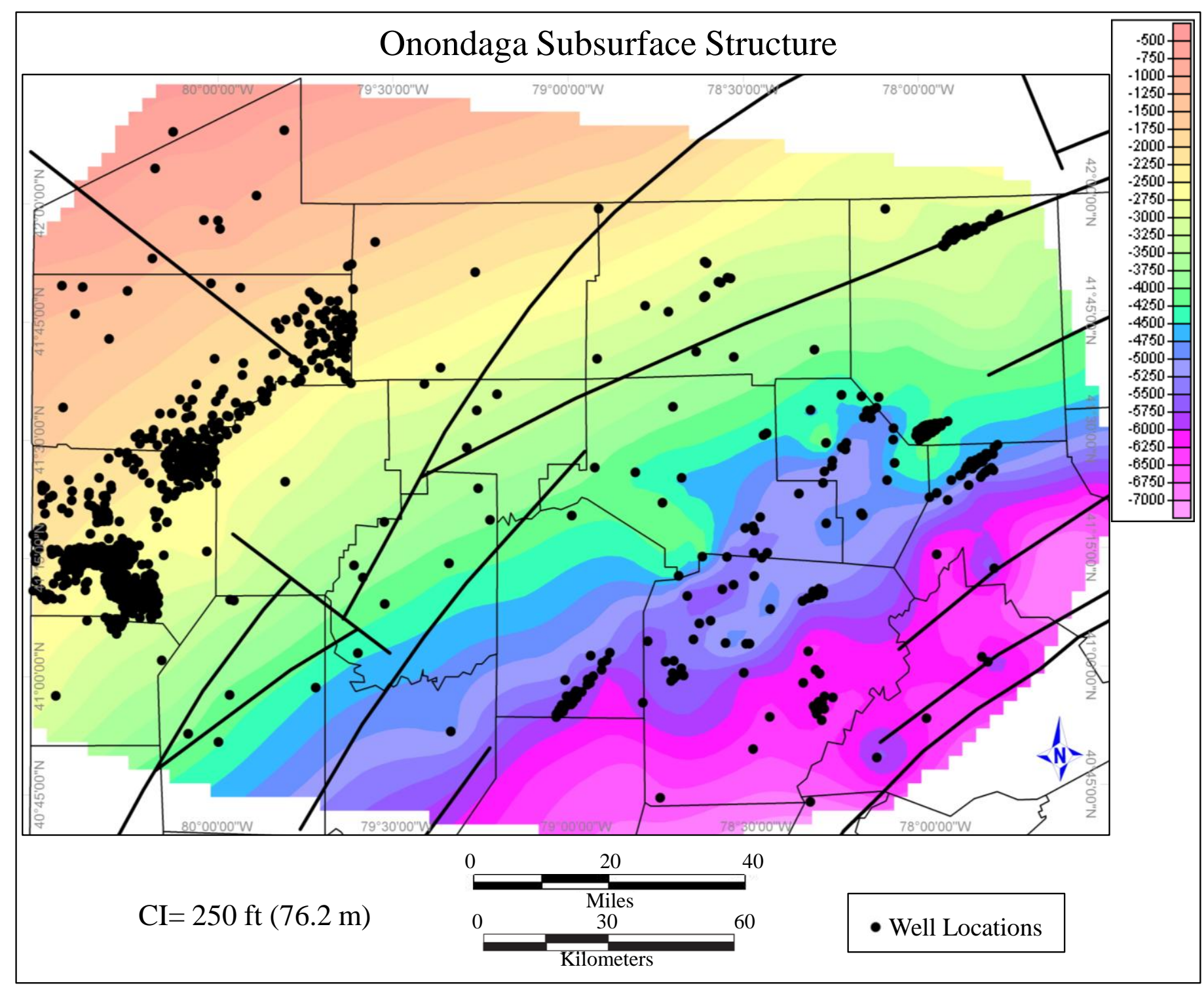

Figure 10- Onondaga subsurface structure trending northeast to southwest with regional faults (W VGES, 2006). 


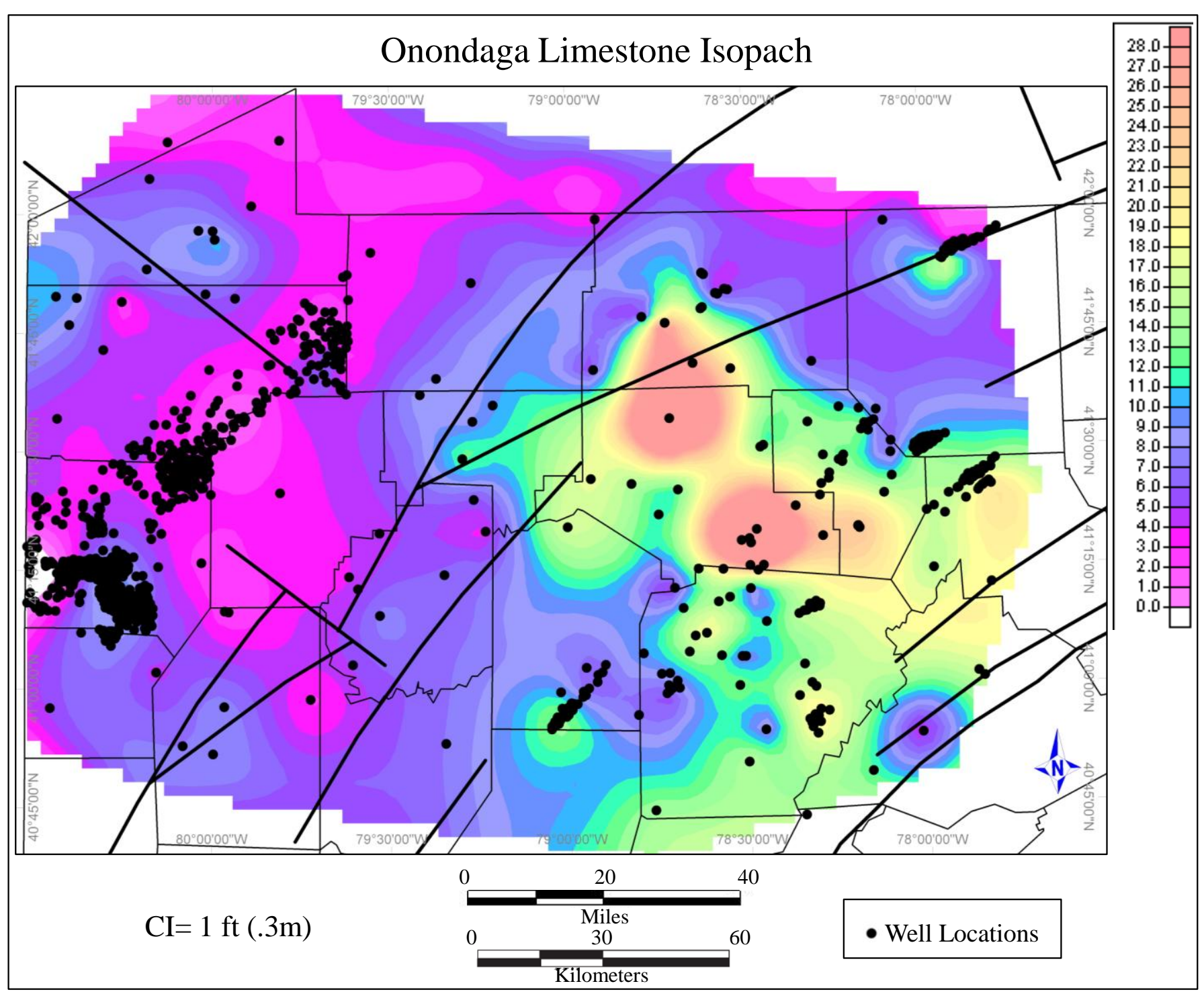

Figure 11- Isopach of Onondaga Limestone with regional faults (W VGES, 2006). 


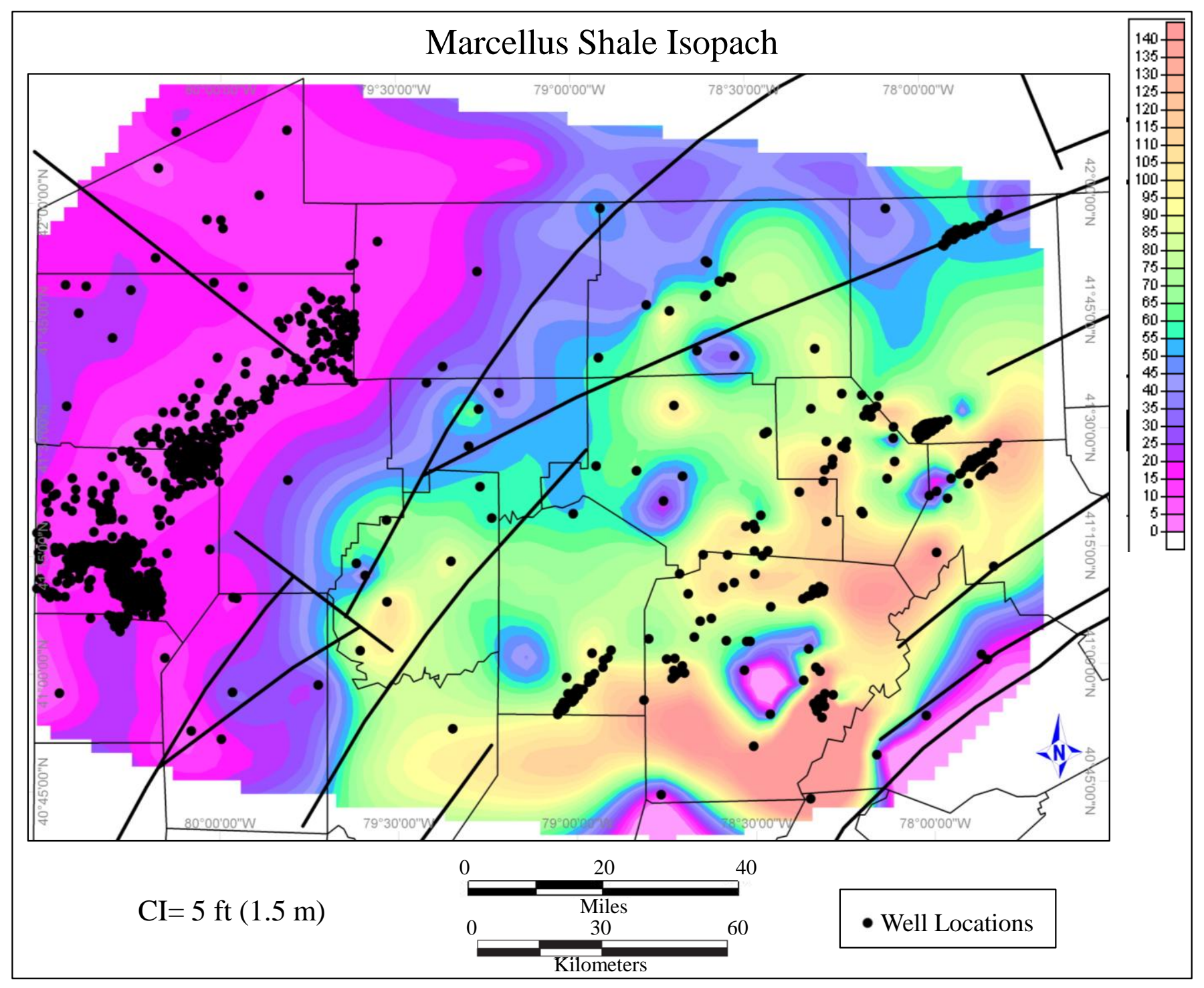

Figure 12- Isopach of Marcellus Shale showing northeast to southwest trend and regional faults (W VGES, 2006). 


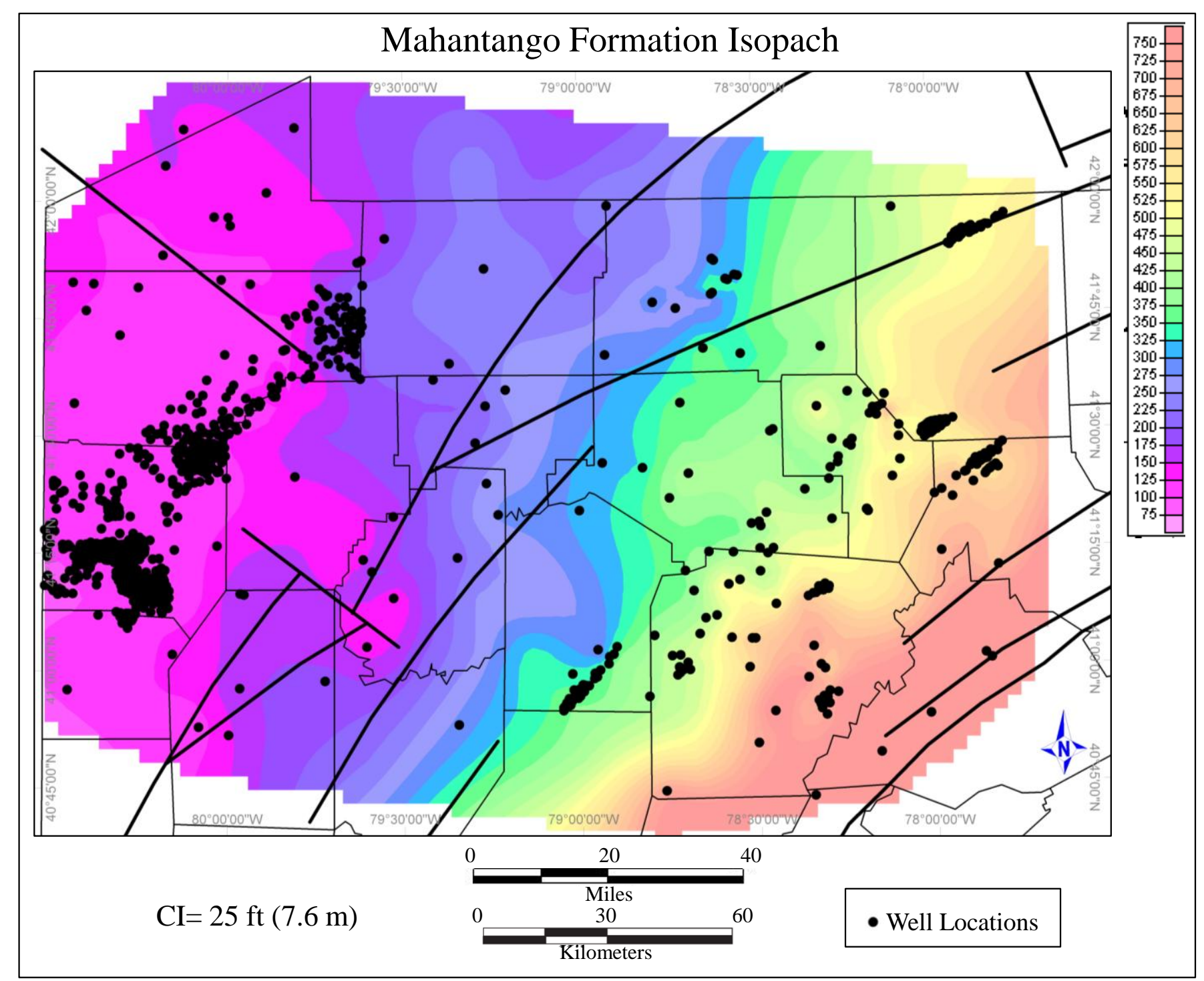

Figure 13- Isopach of the Mahantango showing northeast to southwest trend and regional faults (W VGES, 2006). 


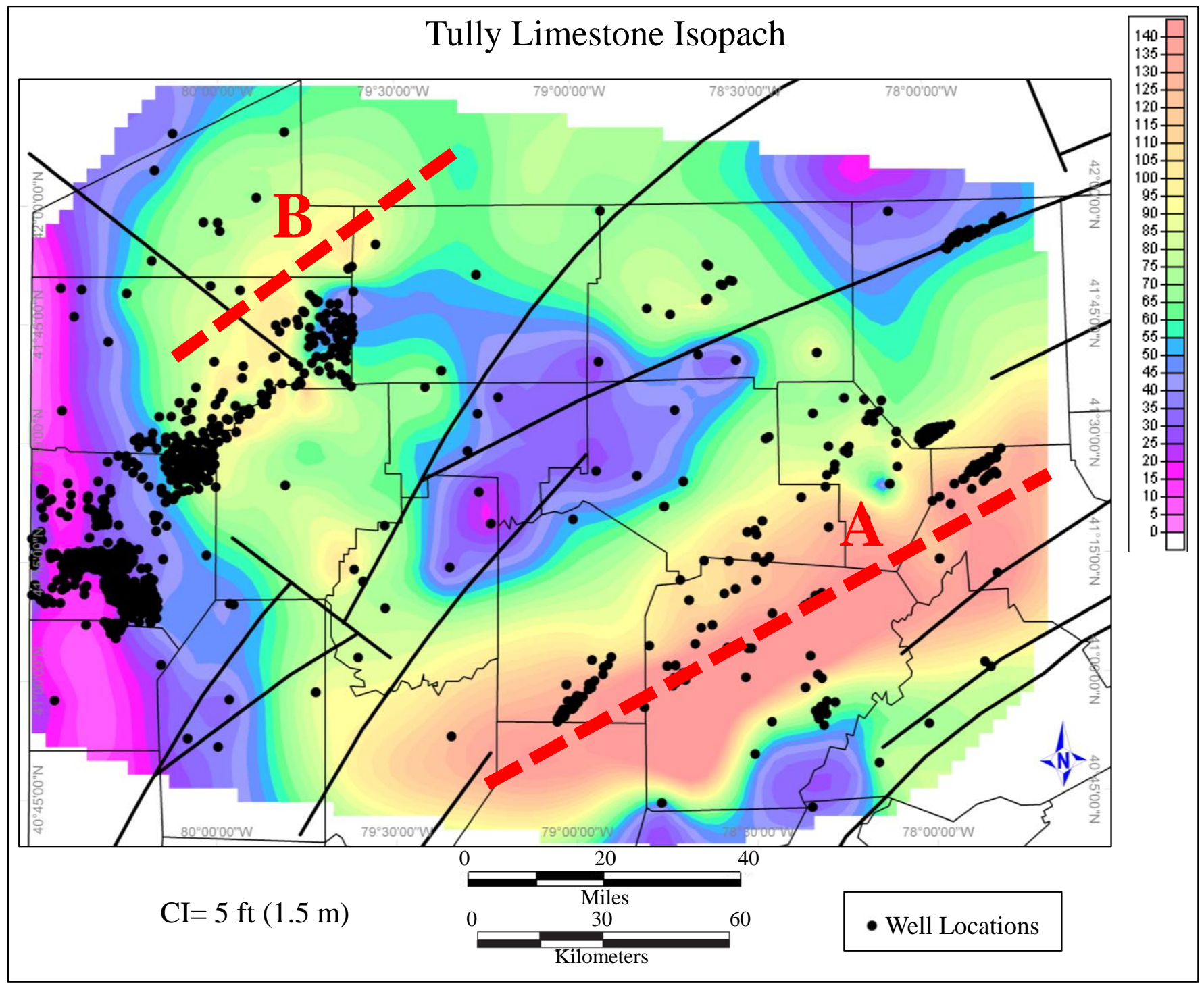

Figure 14- Isopach of the Tully Limestone illustrating highs at A and B with a low between them along with regional faulting (WVGES, 2006). 


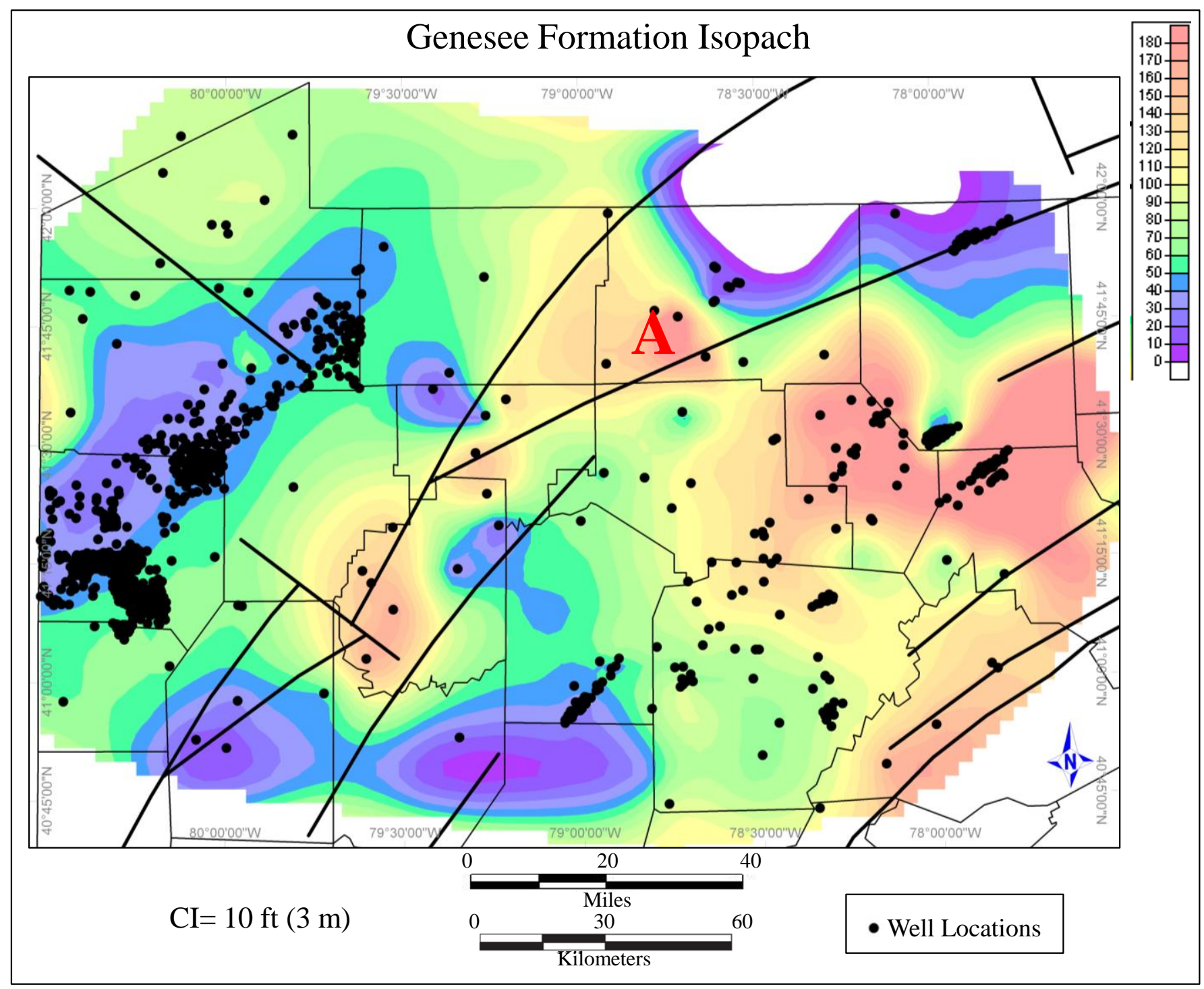

Figure 15- Isopach of the Genesee Formation illustrating a thickness trend (A) along regional faulting (W VGES, 2006). 


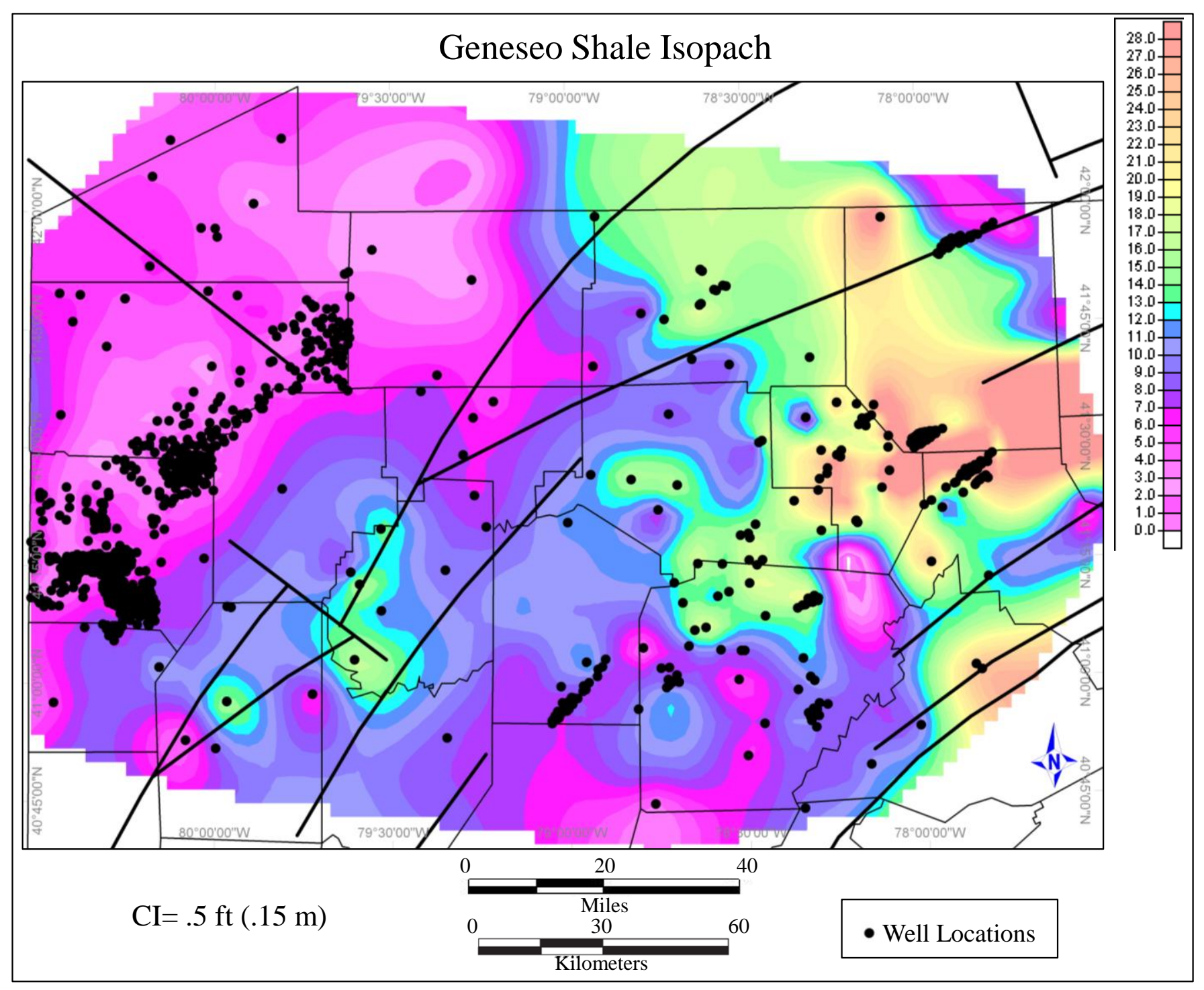

Figure 16- Isopach of Geneseo Shale with reg ional faults (W VGES, 2006). 


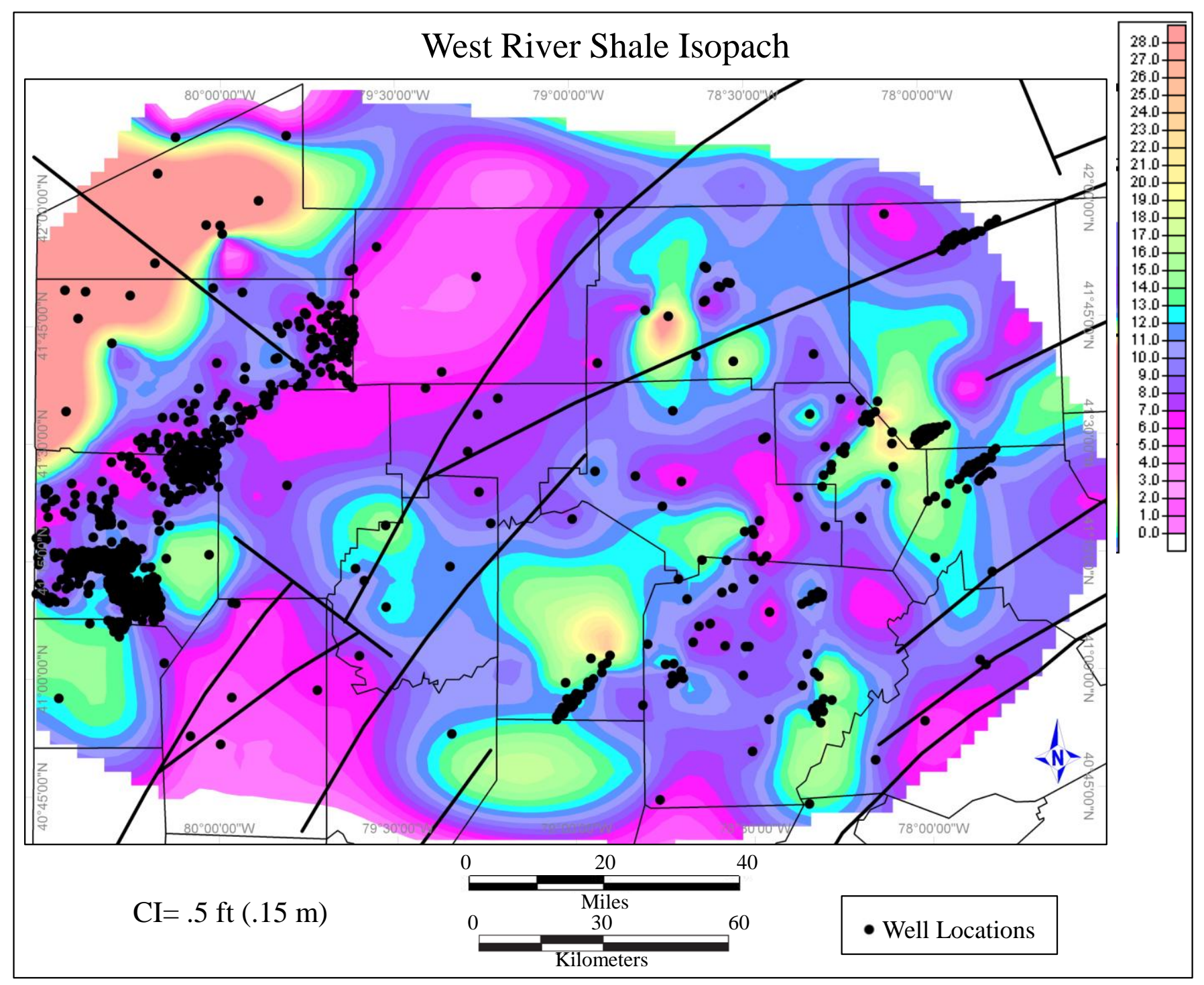

Figure 17- Isopach of West River Shale with regional faulting (W VGES, 2006). 


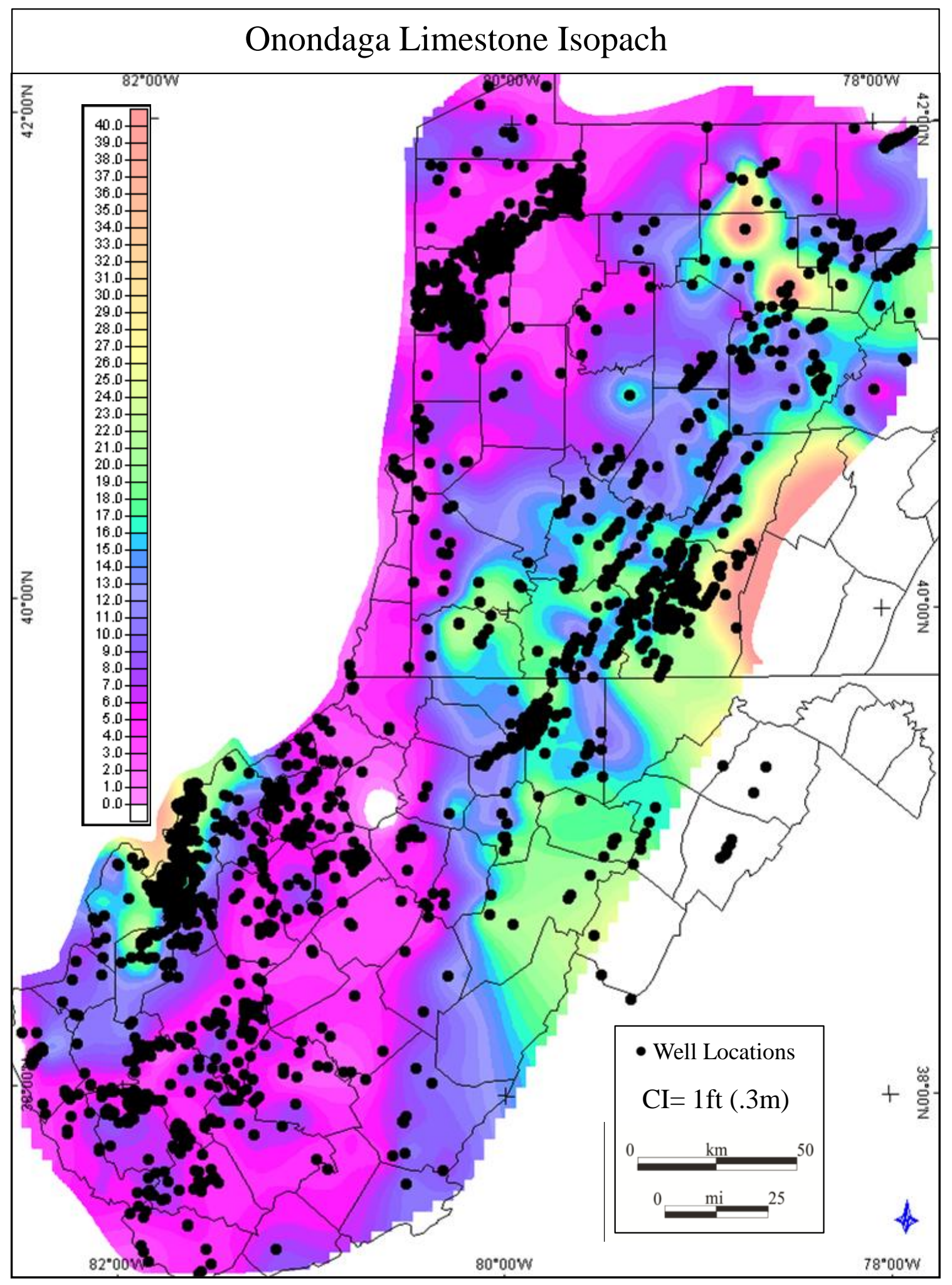

Figure 18- Onondaga Limestone isopach of West Virg inia and western Pennsylvania (Boyce, 2010; Yanni, 2010). 


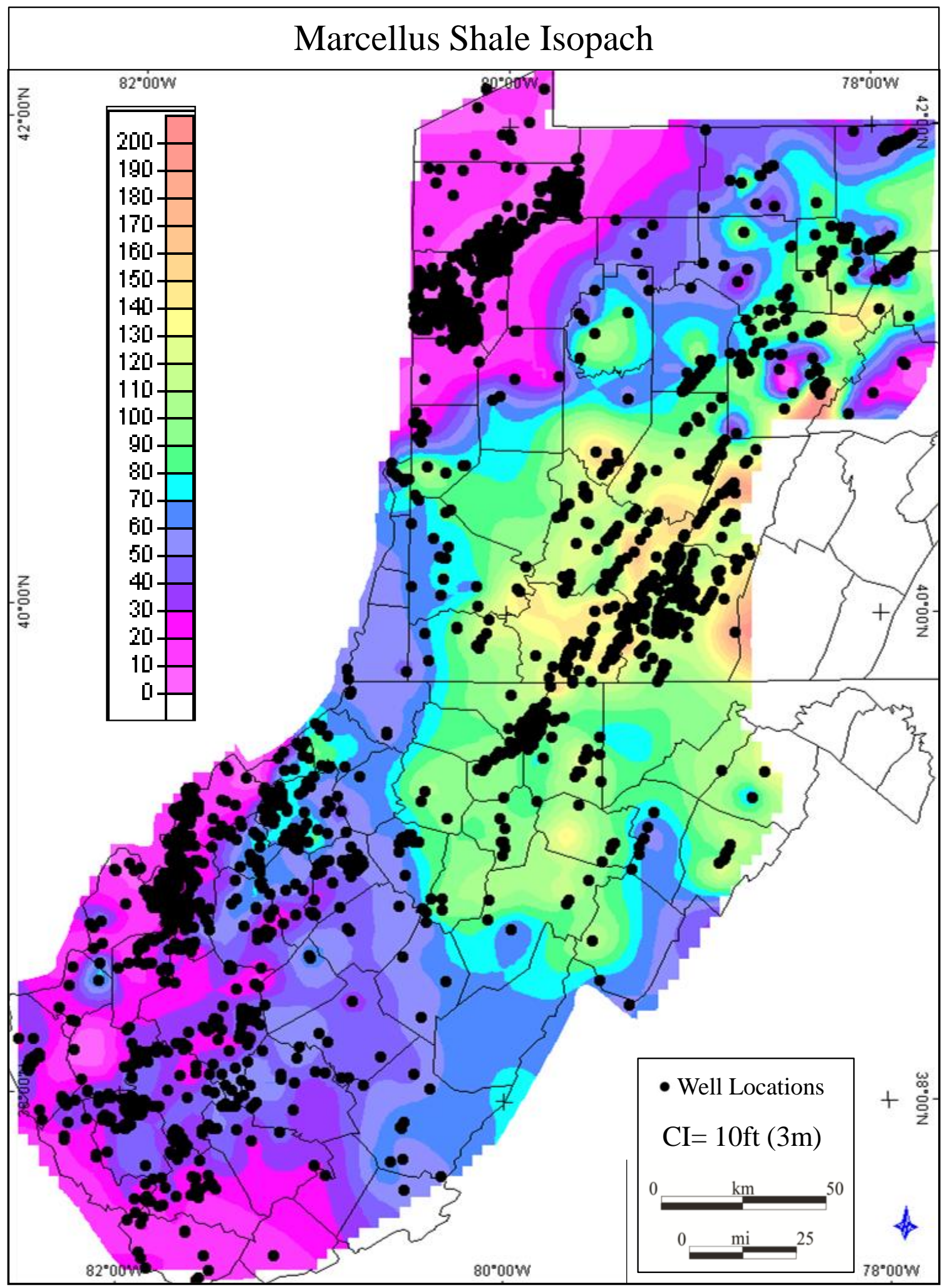

Figure 19- Marcellus Shale isopach of West Virginia and western Pennsylvania (Boyce, 2010; Yanni, 2010). 


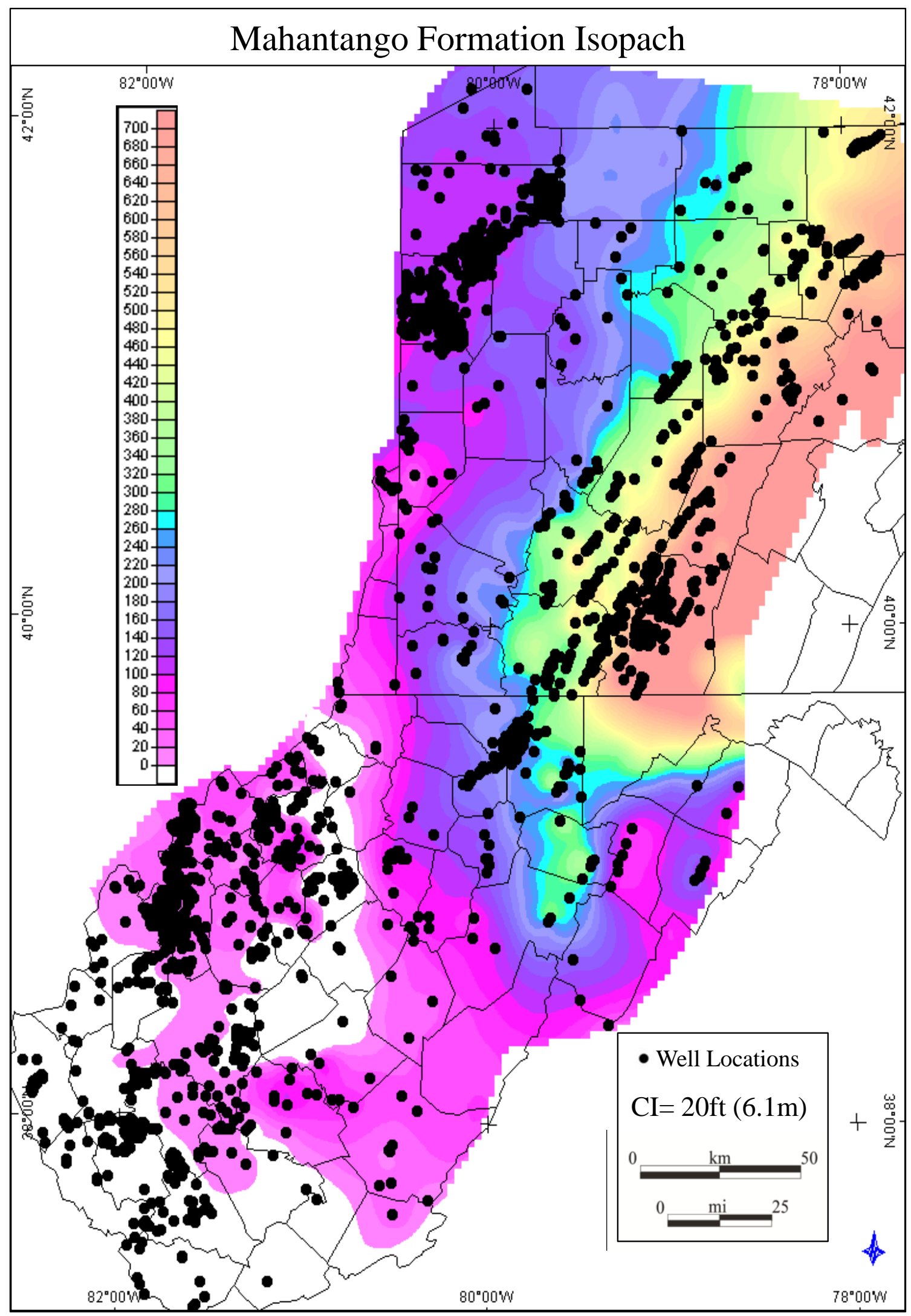

Figure 20- Mahantango Formation isopach for West Virginia and western Pennsylvania (Boyce, 2010; Yanni, 2010). 


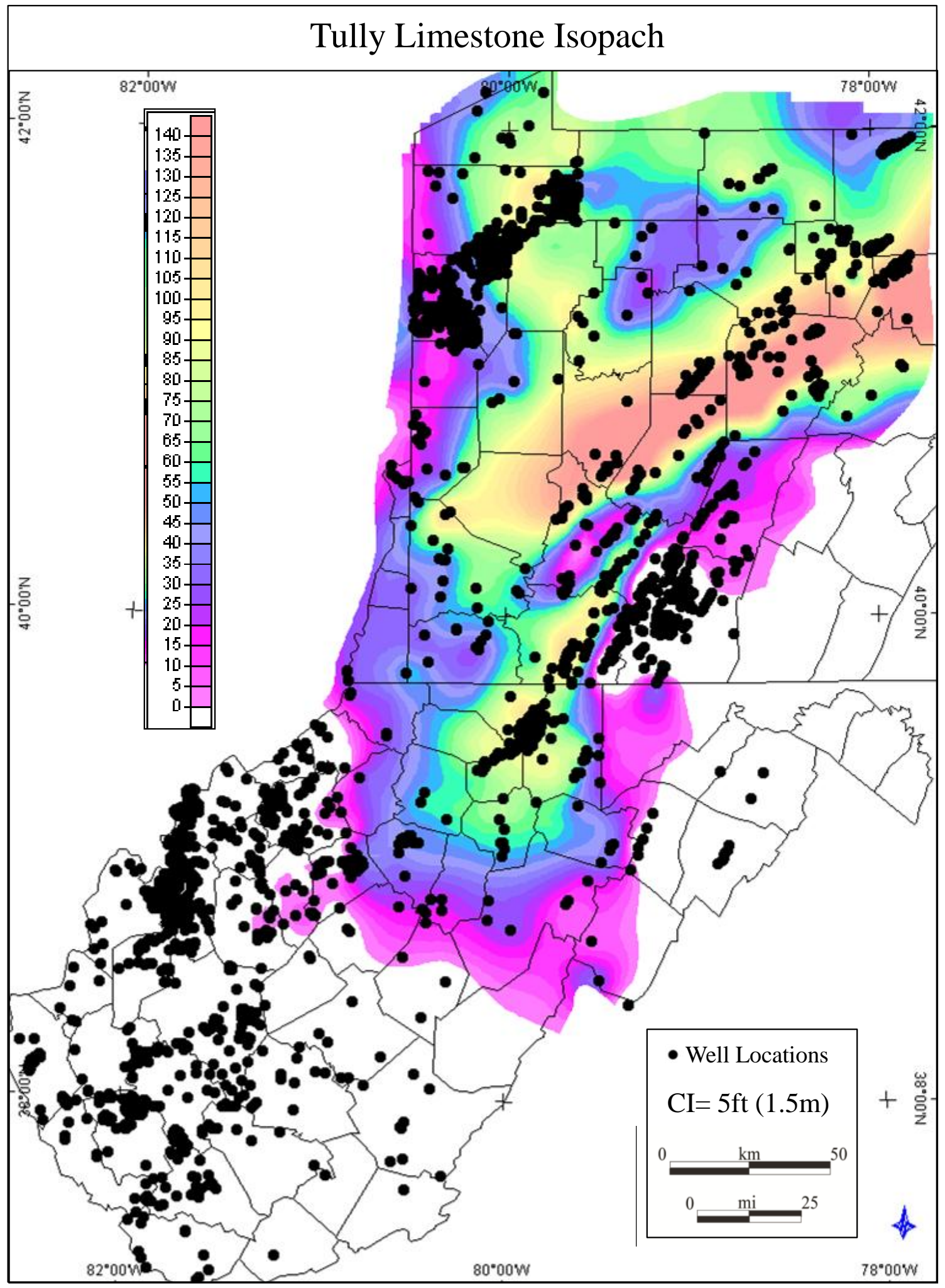

Figure 21- Tully Limestone isopach of West Virg inia and western Pennsylvania (Boyce, 2010; Yanni, 2010). 


\section{ECONOMIC POTENTIAL}

\section{NORTHWESTERN PENNS YLVANIA}

The distribution of the Marcellus Shale and other Middle Devonian units allows an analys is of the subsurface relations hips in northwestern Pennsylvania. Lithologic and petrophysical criteria for evaluating the economic potential of unconventional resources for numerous intervals of the Middle Devonian were established and mapped to better understand the depositional history and resource potential of the region. One of the most important parts of this study is to determine economic potential for the Middle Devonian interval in northwestern Pennsylvania in combination with the economic potential of southwestern Pennsylvania and West Virginia (Boyce, 2010).

Organic-rich areas in the study area are illustrated using several approaches. First, an isopach map was created with gamma-ray values greater than 230 API (Figure 22). Based on Boyce and Carr (2009), gamma-ray values greater than 230 API are indicative of high uranium concentrations associated with high TOC and potential gas-rich intervals. Areas above 230 API are used as a proxy to indicate organic-rich intervals. Second, using the relationship for measured uranium (ppm) and the standard full-spectrum gamma-ray (API) (Boyce and Carr, 2009), a net uranium map was created for the Marcellus Shale to highlight potential areas with higher TOC (Figure 23). Third, interpreted organicrichness maps illustrate a net thickness map with TOC content greater than or equal to $7 \%$ (Figure 24).

The Marcellus Shale isopach map with gamma-ray values greater than 230 API highlights the distinct drop off from high to low gamma-ray values (Figure 22). The areas in the Marcellus Shale with both thickness and high gamma-rays do not strictly 
correlate to net gross thickness of the shale. Gas-rich intervals in the Marcellus Shale are better determined by combining both thickness and higher gamma-ray levels. The net thickness of Marcellus with uranium greater than $15 \mathrm{ppm}$ highlights two northeast trends that correlate to the gamma-ray values over 230 API (Figure 23). The elevated uranium in the Marcellus Shale is interpreted as an indicator of increased gas in place potential (Boyce, 2010). Additionally, Boyce and Carr theorize TOC in the area is controlled by highs and lows of the Onondaga Limestone. An interpreted organic-richness map is illustrated by a net thickness map of the Marcellus Shale with TOC content greater than or equal to $7 \%$ (Figure 24). The red outline illustrates the location of thickest Marcellus Shale from the Marcellus Shale isopach. The areas of thickest organic-rich shale in the Marcellus are basinward of a positive feature defined by the thickness of the underlying Onondaga Limestone and is also basinward of the thickest Marcellus Shale. When the Marcellus Shale interpreted organic-richness (Figure 24) is compared to the underlying Onondaga Limestone structure map (Figure 10), it is evident that organic-richness is controlled by the underlying structure. The most organic-rich Marcellus Shale was deposited when the Onondaga Limestone was at a topographic low. This relationship shows that the organic-richness in the Marcellus Shale is controlled by the highs and lows of the Onondaga Limestone.

Organic-rich areas in the Genesee Formation are also estimated using an isopach map with gamma-ray values greater than 230 API (Figure 25). An interpreted organicrichness map throughout the Genesee Formation shows the TOC content greater than or equal to $7 \%$ highlighting areas of organic-richness throughout the study area (Figure 26). The Geneseo Shale net gamma-ray map shows the areas of highest gamma-ray are in 
central Pennsylvania (Figure 27) and interpreted organic-richness for the Geneseo Shale is toward the east (Figure 28). The West River Shale net gamma-ray map highlights the most northwestern tip of Pennsylvania as the area with the most potential (Figure 29) and interpreted organic-richness for the West River Shale is toward the northwest (Figure 30).

\section{APPALACHIAN BASIN: WEST VIRGINIA AND WESTERN PENNSYLVANIA}

In West Virginia and western Pennsylvania, an interpreted organic-richness map of the Marcellus Shale is a regional view of the net thickness with TOC content greater than or equal to 7\% (Figure 31) (Boyce, 2010; Yanni, 2010). Off the Onondaga Limestone shelf, the organic-rich Marcellus Shale has a surplus of organic matter from the Onondaga shelf related to decreased detrital input, insufficient currents of removal, and low biogenic recycling allowing organic matter to accumulate in the sediment. Localized rapid changes in interpreted thick TOC accumulations are tied to local structures. The areas of highest TOC are identified by their relation to the underlying structure at the time of deposition and not by the gross unit thickness of the shale. The thickest portions of the Onondaga Limestone are highlighted inside the red outlines (Figure 32). The relationship between organic-rich Marcellus Shale and thickness of the Onondaga varies. Some of the organicrich areas of the Marcellus Shale occur on the edge of the distinct drop off point between thick and thin Onondaga Limestone. Other organic-rich areas of the Marcellus Shale occur on top of the thickest Onondaga Limestone while other areas of organic-richness occur where the Onondaga Limestone is thinner. 


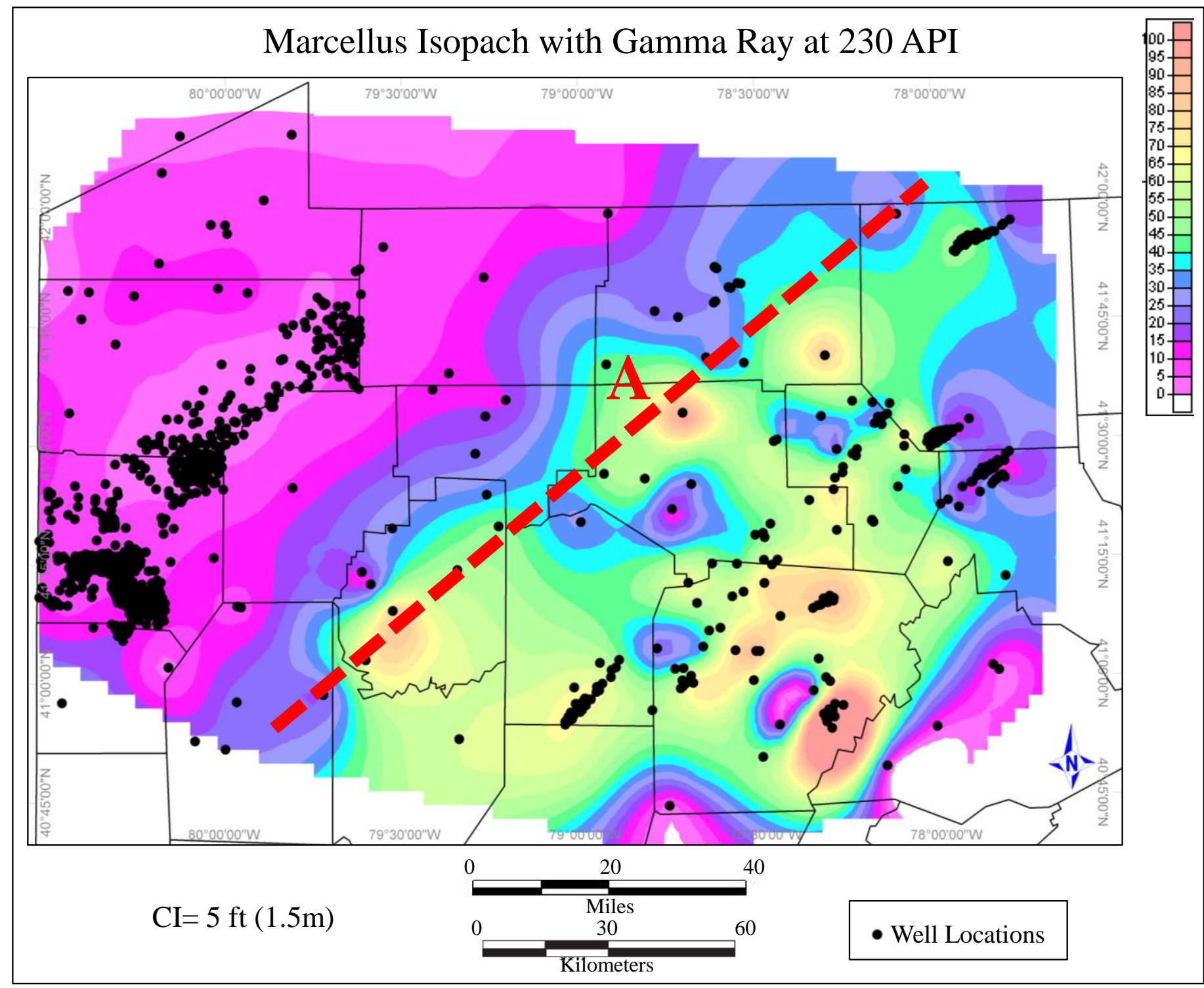

Figure 22- Organic-rich areas in the Marcellus Shale are shown using an isopach map with gamma-ray values greater than 230 API. Trend A highlights the distinct drop off from high to low gamma-ray values. 


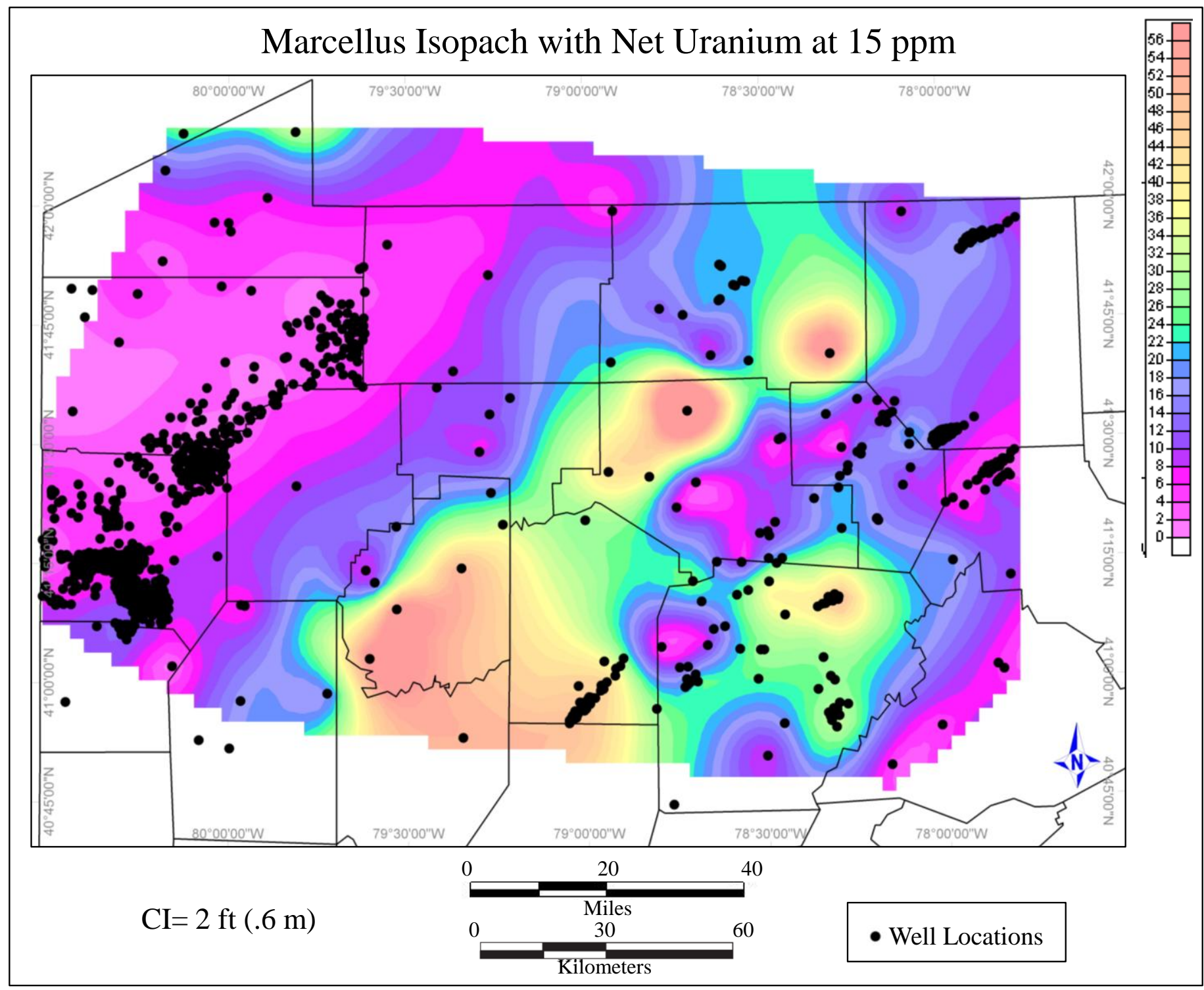

Figure 23- Net uraniu m map was created for the Marcellus interval at $15 \mathrm{ppm}$ to highlight potential areas with higher TOC. 


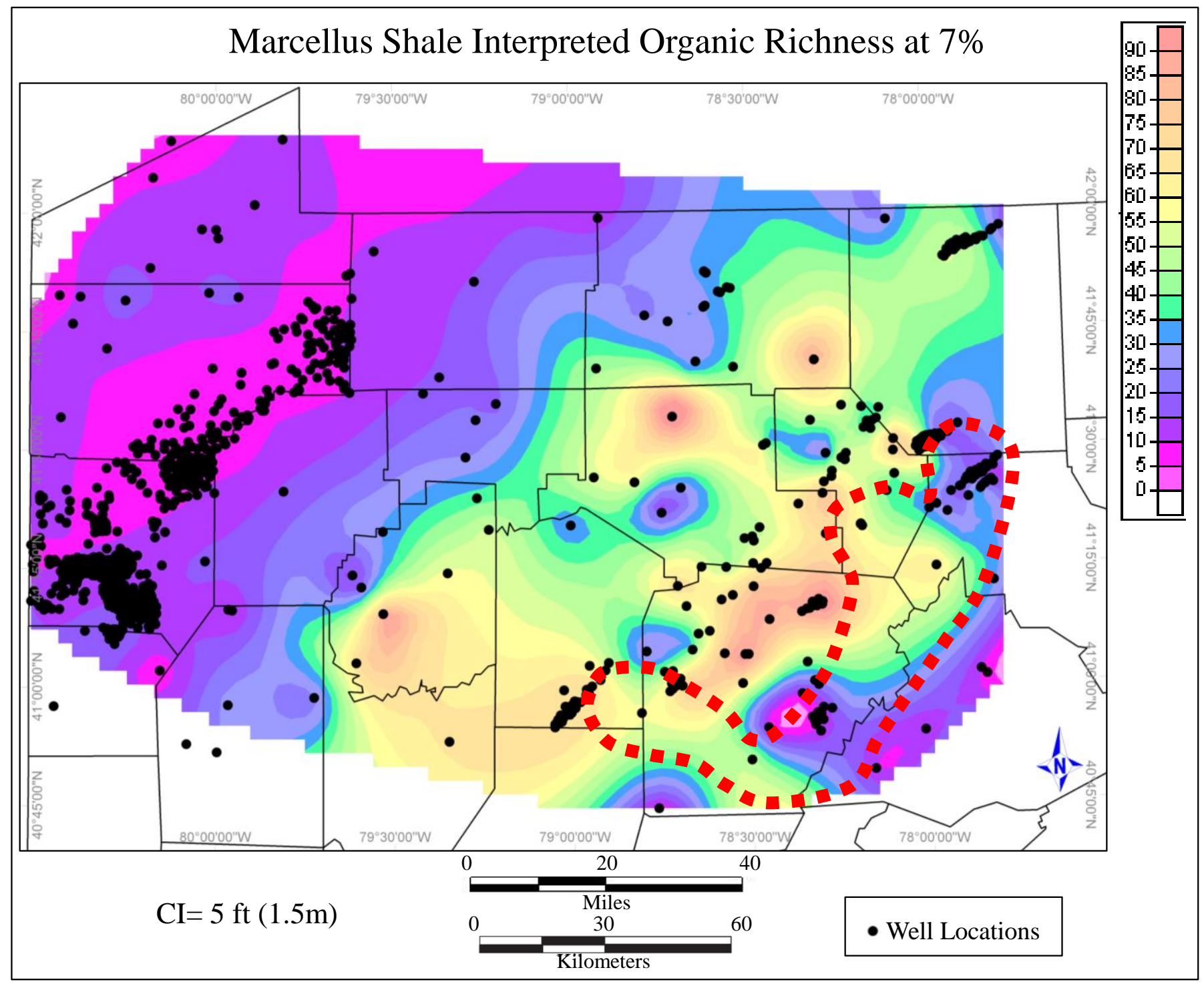

Figure 24- Interpreted organic-richness map illustrated by a net thickness map of the Marcellus Shale with TOC content greater than or equal to 7\%. The red outline illustrates the location of thickest Marcellus Shale from the Marcellus Shale isopach. 


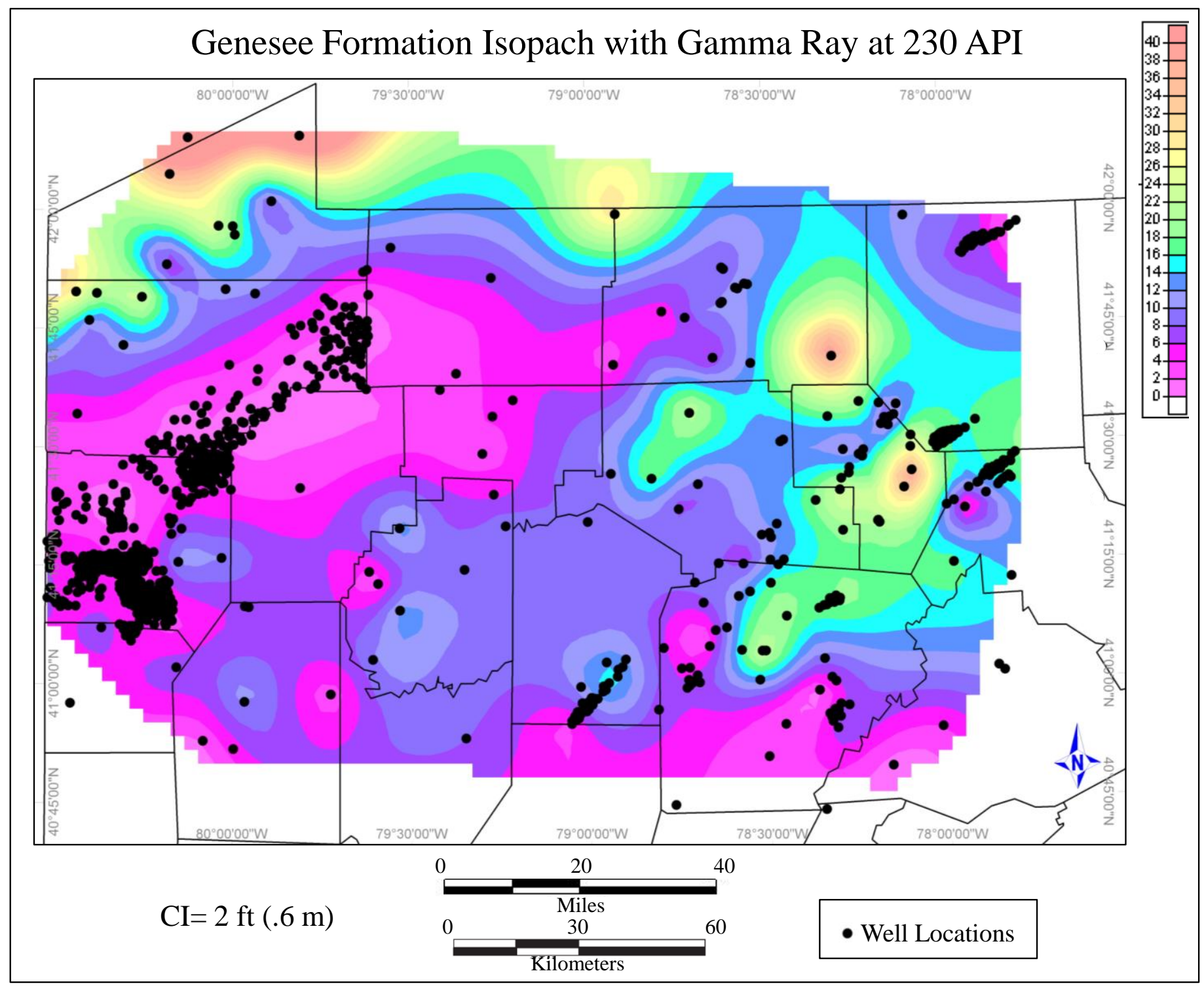

Figure 25- Organic-rich areas in the Genesee Formation are shown using an isopach map with gamma-ray values greater than 230 API. The areas with the highest gamma-ray values are toward the eastern portion and the northwestern corner of the study area. 


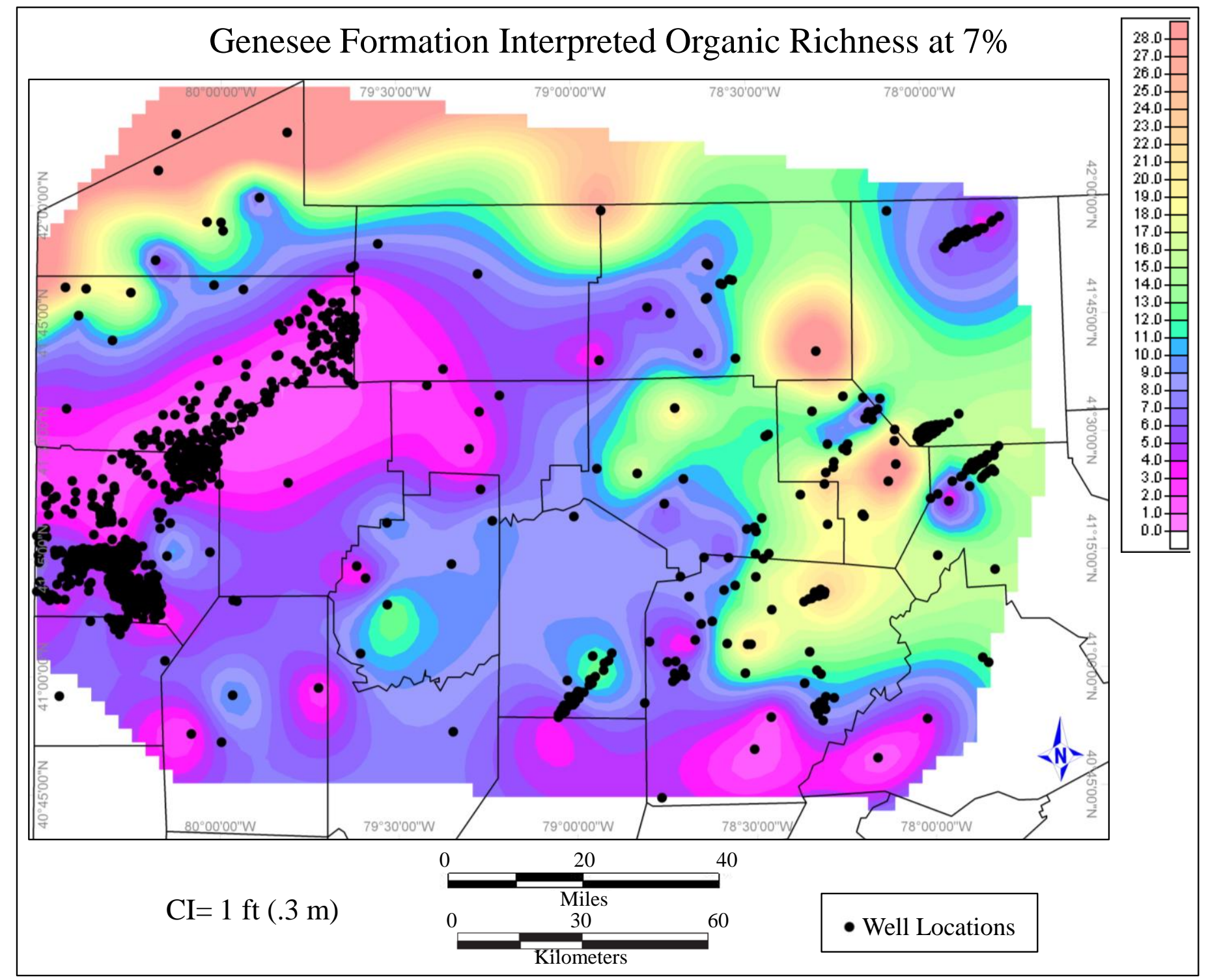

Figure 26- Interpreted organic-richness map illustrated by a net thickness map of the Genesee Formation with TOC content greater than or equal to $7 \%$. 


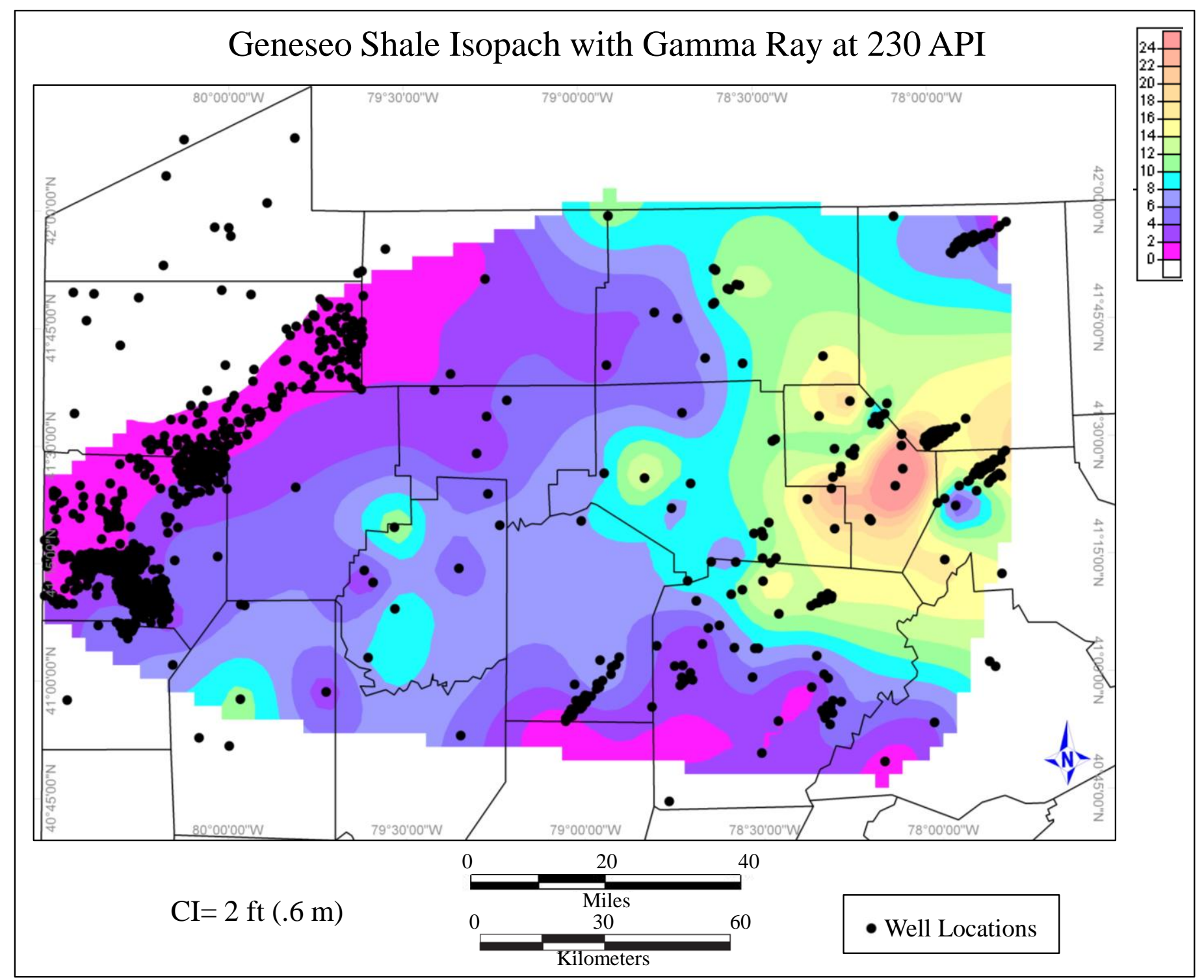

Figure 27- Organic-rich areas in the Geneseo Shale Member of the Genesee Formation are shown using an isopach map with gamma-ray values greater than $230 \mathrm{API}$. The areas with the highest gamma-ray values are to the east. 


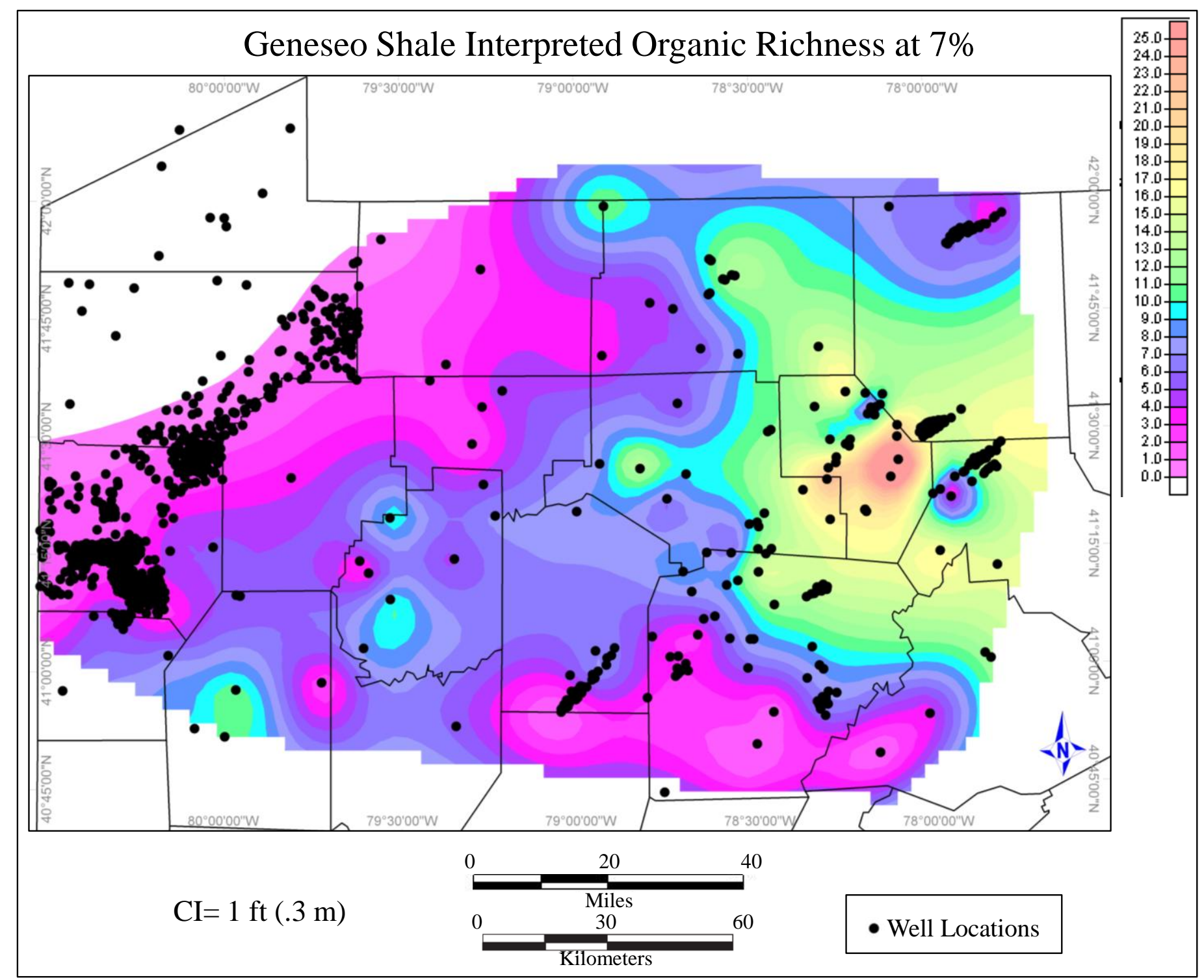

Figure 28- Interpreted organic-richness map illustrated by a net thickness map of the Geneseo Shale with TOC content greater than or equal to $7 \%$. 


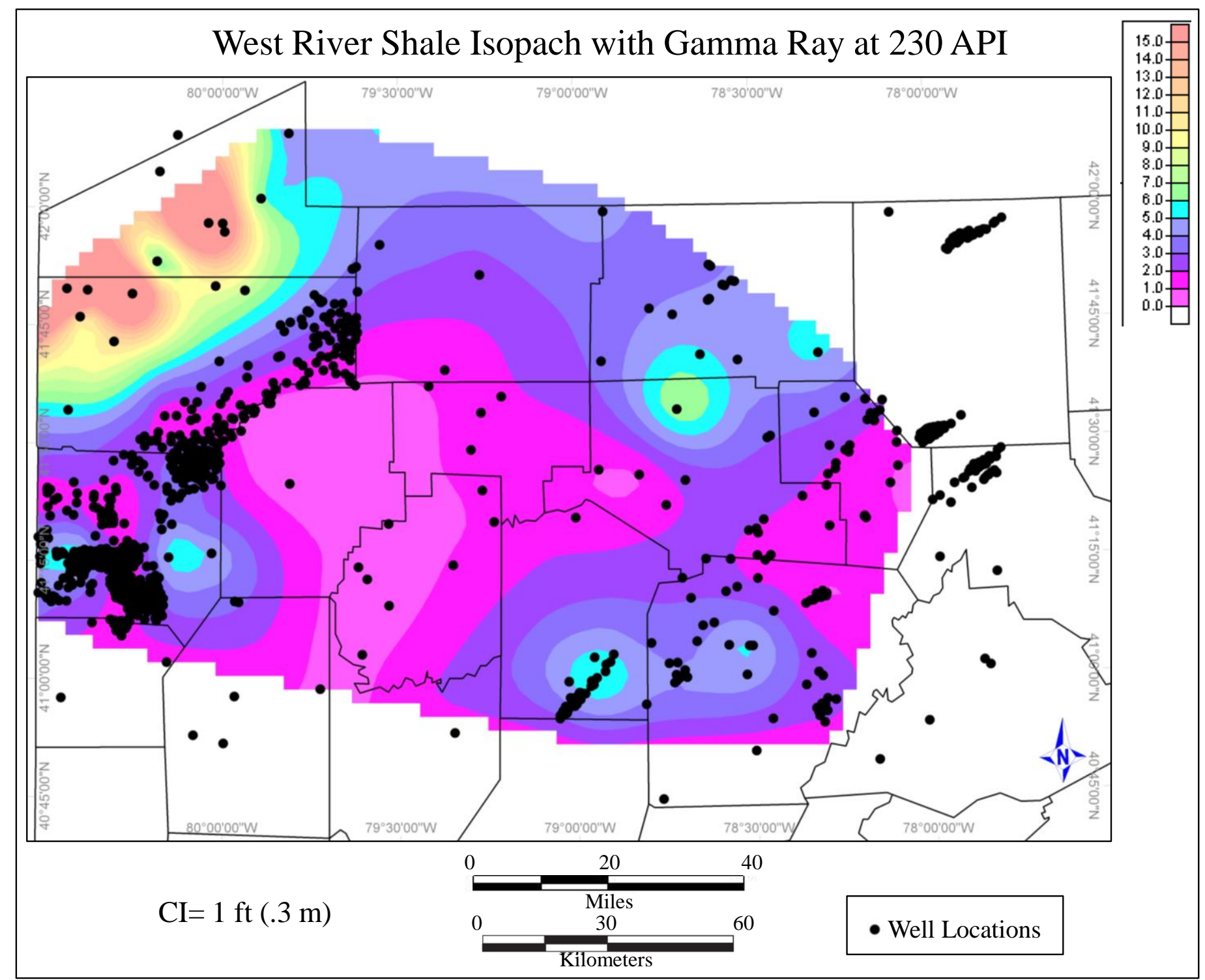

Figure 29- Organic-rich areas in the West River Shale Member of the Genesee Formation are shown using an isopach map with gamma-ray values greater than $230 \mathrm{API}$. The areas with the highest gamma-ray are to the northwest. 


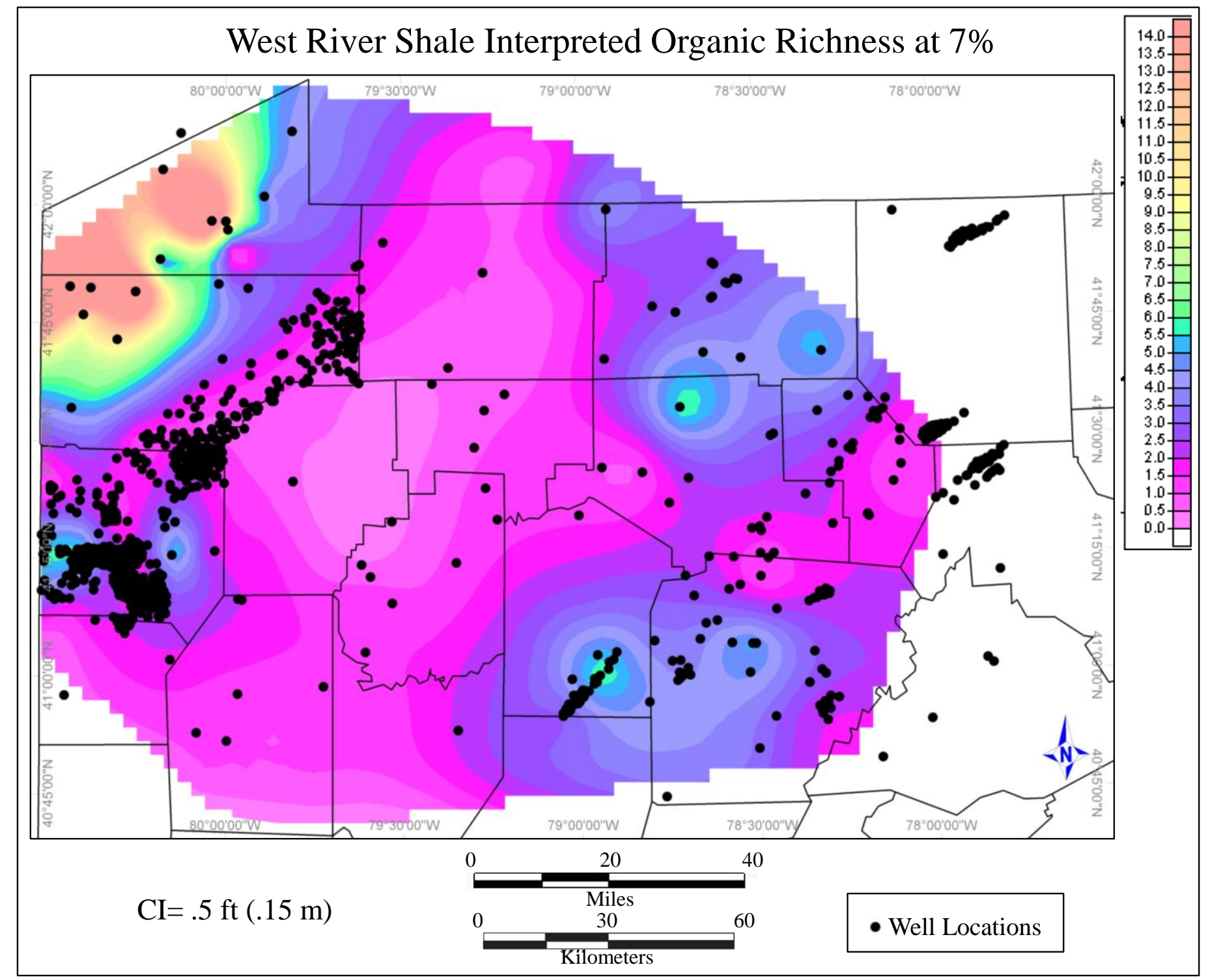

Figure 30- Interpreted organic-richness maps of the West River Shale show TOC content greater than or equal to $7 \%$ highlighting areas of organic-richness throughout the study area. 


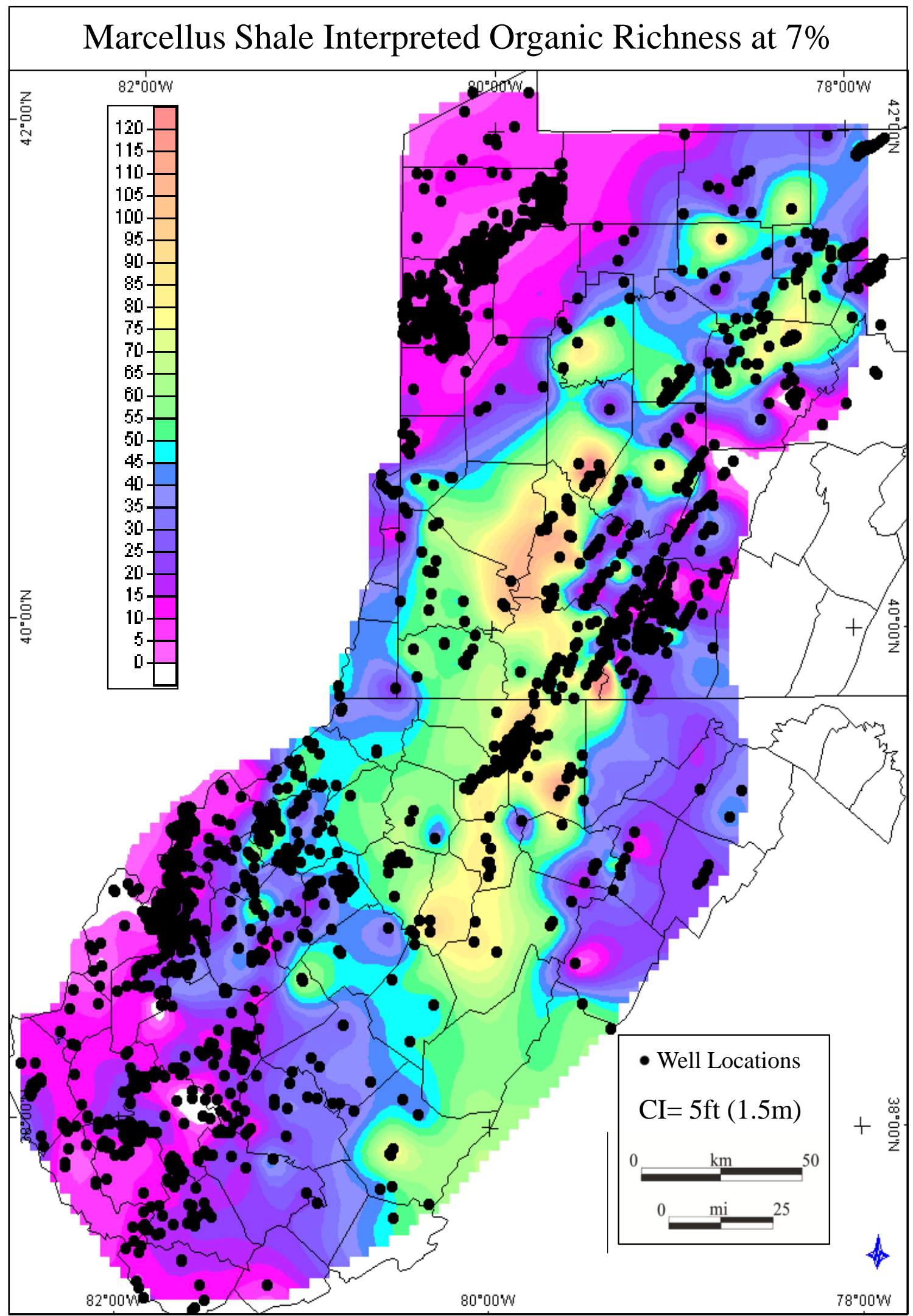

Figure 31- Interpreted organic-richness map illustrated by a net thickness map of the Marcellus Shale with TOC content greater than or equal to $7 \%$. Localized rapid changes in interpreted thick TOC accumu lations are tied to local structures that appear to be a result of salt tectonics or reactivated structure during the Acadian Orogeny (Boyce and Carr, 2010; Yanni, 2010). 


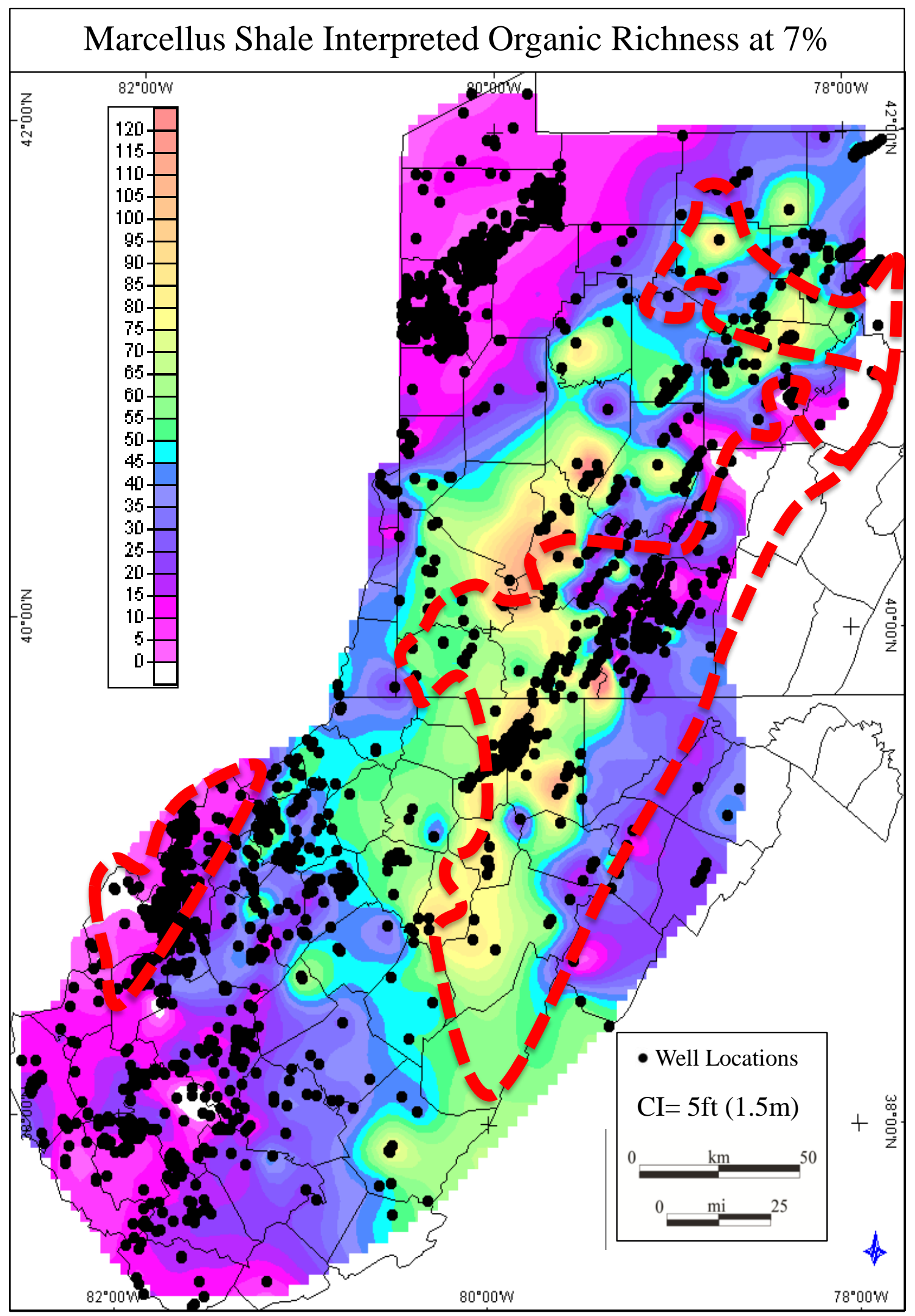

Figure 32- Interpreted organic-richness map illustrated by a net thickness map of the Marcellus Shale with TOC content greater than or equal to $7 \%$. The thickest portions of the Onondaga Limestone are highlighted inside the red outlines (Boyce, 2010; Yanni, 2010). 


\section{CONCLUSIONS}

This study is an analysis of the subsurface relationships and petrophysics of the Middle Devonian interval in northwestern Pennsylvania. Lithologic and petrophysical criteria for evaluating the economic potential of unconventional resources for shale-rich intervals in the Middle Devonian were established and mapped to better understand depositional history and resource potential.

The following criteria were used to determine subsurface unit boundaries. The Onondaga Limestone has a gamma-ray value of 30-110 API, a photo electric value of approximately 5 barns/electron, and a bulk density value of $2.71 \mathrm{~g} / \mathrm{cc}$. The Marcellus Shale has gammaray values greater than $200 \mathrm{API}$ and bulk density less than $2.55 \mathrm{~g} / \mathrm{cc}$. The Mahantango has a gamma-ray value below 200 API and a bulk density value greater than $2.55 \mathrm{~g} / \mathrm{cc}$. The Tully Limestone has a cleaner gamma-ray value of 30-110 API, a PE value of approximately 5 barns/electron, and a bulk density value of $2.71 \mathrm{~g} / \mathrm{cc}$. The Geneseo Shale Member of the Genesee Formation is characterized with gamma-rays of over 200 API and a bulk density less than $2.55 \mathrm{~g} / \mathrm{cc}$. The Penn Yann Shale and West River members of the Genesee Formation have a bulk density below $2.55 \mathrm{~g} / \mathrm{cc}$. The Penn Yan has gamma- rays of approximately $100 \mathrm{API}$, and is distinguishable from the West River Shale because the West River Shale has a gamma-ray value over 200 API.

Organic-rich areas in the study area are illustrated using several approaches. First, an isopach map was created with gamma-ray values greater than 230 API (Figure 22). Based on Boyce and Carr (2009), gamma-ray values greater than 230 API are indicative of high uranium concentrations associated with high TOC and potential gas-rich intervals. Areas above 230 API are used as a proxy to indicate organic-rich intervals. Second, using the 
relationship for measured uranium (ppm) and the standard full-spectrum gamma-ray (API) (Boyce and Carr, 2009), a net uranium map was created for the Marcellus Shale to highlight potential areas with higher TOC (Figure 23). Third, interpreted organicrichness maps illustrate a net thickness map with TOC content greater than or equal to $7 \%$ (Figure 24).

The Geneseo Shale net gamma-ray map shows the areas of highest gamma-ray are in central Penns ylvania (Figure 27) and interpreted organic-richness for the Geneseo Shale is toward the east (Figure 28). The West River Shale net gamma-ray map highlights the most northwestern tip of Pennsylvania as the area with the most potential (Figure 29) and interpreted organic-richness for the West River Shale is toward the northwest (Figure 30).

When the Marcellus Shale interpreted organic-richness (Figure 24) is compared to the underlying Onondaga Limestone structure map (Figure 10), it is evident that organicrichness is controlled by the underlying structure. The most organic-rich Marcellus Shale was deposited when the Onondaga Limestone was at a topographic low. This relationship shows that the organic-richness in the Marcellus Shale is controlled by the highs and lows of the Onondaga Limestone.

In northwestern Pennsylvania, gas-rich intervals in the Marcellus Shale are better determined by combining both thickness and higher gamma-ray levels. The areas of thickest organic-rich shale in the Marcellus are basinward of a positive feature defined by the thickness of the underlying Onondaga Limestone and are also basinward of the thickest Marcellus Shale. The most organic-rich areas are present where the thickness of the Marcellus Shale varies. The organic-richness map also shows localized rapid changes 
in interpreted thick TOC accumulations are tied to local structures. The accumulation of thick organic-rich Marcellus Shale is interpreted as the interplay of decreased detrital input and increased organic production. These favorable areas appear to be closely related to favorable paleooceanographic conditions such as distance from sediment source and organic production related to paleotopography of the sea floor. These conditions define an exploration fairway through western Pennsylvania in terms of increased gas in place potential. 


\section{REFERENCES CITED}

Anderson, R. J. and others,1984, American Association of Petroleum Geologists Correlation Chart; Series 1984.

Algeo, T.J., and Scheckler, S.E., 1998, Terrestrial-marine teleconnections in the Devonian; links between the evolution of land plants, weathering processes, and marine anoxic events: Philosophical Transactions-Royal Society of London.Biological Sciences, v. 353, p. 113-130.

Arthur, Michael A., and Bradley B. Sageman. "Marine Black Shales: Depositional Mechanisms and Environments of Ancient Deposits." Annual Review of Earth and Planetary Sciences 22 (1994): 499-551.

Berg, T.M., McInerney, M.K. Way, J.H., and MacLachlan, D.B., 1986, Stratigraphic Correlation Chart of Pennsylvania, 2nd printing, revised, Pennsylvania Geological survey, 4th ser., Map 63, scale 1:500,000.

Blakey, Ron. "Ron Blakey, Global and Regional Paleogeography." NAU Geology. 21 June $2010<$ http://jan. ucc.nau.edu/ rcb7/>.

Blatt, Harvey, and Robert J. Tracy. Petrology: Igneous, Sedimentary, and Metamorphic. 2nd ed. New York: W.H. Freeman and Company, 2000. 281-92.

Boyce, M. L. and T. R. Carr, Lithostratigraphy and Petrophysics of the Devonian Marcellus Interval in West Virginia and Southwestern Pennsylvania, in T. R. Carr and N. C. Rosen, eds., Unconventional Resources: Making the Unconventional Conventional, Gulf Coast Section SEPM, Publication that is the product of the 29th Bob F. Perkins Research Conference, December 6-8, 2009 in Houston, Texas, US A, 2009. p. 254-281.

Boyce, M. L., Sub-surface Stratigraphy and Petrophysical Analysis of the Middle Devonian Interval of the Central Appalachian Basin; West Virginia and Southwest Pennsylvania, unpublished PhD Dissertation, West Virginia University, 2010. 144p.

Dickinson, W.R., 1974, Plate tectonics and sedimentation, in Dickinson, W.R., ed., Tectonics and sedimentation: SEPM Spec. Pub. 22, p. 1-27.

Demaison, G. J. and G. T. Moore, 1980, Anoxic environments and oil source bed genesis: AAPG Bulletin, v. 64, no. 8, p. 1179-1209.

de Witt, Wallace, Jr., Roen, J.B., and Wallace, L.G., 1993, Stratigraphy of Devonian black shales and associated rocks in the Appalachian basin, IN Roen, J.B., and Kepferle, R.C., eds., Petroleum geology of the Devonian and Mississippian black shale of eastern North America: U.S. Geological Survey Bulletin, 1909-B, p. B1-B57. 
Engelder, Terry, and Gary G. Lash, 2008. "Marcellus Shale Play's Vast Resource Potential Creating Stir in Appalachia." The American Oil and Gas Reporter. May 2008.

Ettensohn, F.R., and Janka, J.C., 1984, The nature and effects of water depth during deposition of the Devonian-Mississippian black shale; Proceedings; 1984 eastern oil shale symposium: Proceedings - Eastern Oil Shale Symposium, v. IMMR84/124, p. 333346.

Ettensohn, F.R., 1985, The Catskill Delta complex and the Acadian orogeny: A model, in Woodrow, D.L. \& Sevon, W.D. (Eds.): The Catskill Delta. - Geol. Soc. Amer. Spec. Pap. 201: 39-49.

Ettensohn, F.R., 1987, Rates of relative plate motion during the Acadian orogeny based on the spatial distribution of black shales. J. Geol. 95:572-582.

Ettensohn, F.R., 1994, Marine, organic-rich, dark-shale deposition on North American parts of Pangea, Carboniferous to Jurassic; effects of supercontinent organization; Pangea; global environments and resources: Memoir - Canadian Society of Petroleum Geologists, v. 17, p. 743-762.

Ettensohn, F.R., 1998, Compressional tectonic controls on epicontinental black-shale deposition; Devonian-Mississippian examples from North America, in Schieber, J., Zimmerle, W. and Sethi, P.S., eds., Shales and mudstones; I, Basin studies, sedimentology, and paleontology: Federal Republic of Germany (DEU), E. Schweizerbart'sche Verlagsbuchhandlung Naegele u. Obermiller, Stuttgart, Federal Republic of Germany (DEU) .

Ettensohn, F.R., and Barron, L.S., 1982, A tectonic-climatic approach to the deposition of the Devonian-Mississippian black-shale sequence of North America; Proceedings of the 1982 Eastern oil shale symposium: Proceedings - Eastern Oil Shale Symposium, v. 1982, p. 5-37.

Faill, R. T., 1997, A Geologic History of the North-Central Appalachians, Part 2: The Appalachian Basin from the Silurian Through the Carboniferous; Americ an Journal of Science, Vol 297 P729-761.

Faill, R.T., and Wells, R.B. (1974), Geology and mineral resources of the Millerstown quadrangle, Perry, Juniata, and Snyder Counties, Pennsylvania, Pennsylvania Geological Survey, $4^{\text {th }}$ ser., Atlas 136, 276 p. 
Fertl, W. H., and H. H. Rieke, 1980, Gamma-ray spectral evaluation techniques identify fractured shale reservoirs and source-rock characteristics: Journal of Petroleum Technology, v. 31, p. 2053-2062.

Fettke, C.R., 1961, Well-sample descriptions in northwestern Penns ylvania and adjacent states, Pennsylvania Geological Survey, $4^{\text {th }}$ ser., Mineral Resource Report 40, 691 p.

Fischer, A.G., 1984, The two Phanerozoic supercycles, in W.C. Berggren and J.A. Van Couvering (Eds.): Catastrophes and Earth History. Princeton, Princeton University Press, 129-150.

Gold, R, 2008, Gas producers rush to Penns ylvania: promising results there spur investment: The Wall Street Journal, page A2. 02 April 2008.

Harper, John A., 1999, Geology of Pennsylvania: Chapter 7, Devonian. Harrisburg, Pa: Pennsylvania Geological Survey, Pittsburgh Geological Society.

Harper, John A., 2008, The Marcellus Shale- An Old 'New" Gas Reservoir in Pennsylvania: Pennsylvania Geology, v. 38, No. 1, p. 2-13.

Harper, J.A., and Piotrowski, R.G., 1979, Stratigraphic correlations of surface and subsurface Middle and Upper Devonian, southwestern Pennsylvania, in Dennison, J.M., and others, Devonian shales in south-central Pennsylvania and Maryland, Annual Field Conference of Pennsylvania Geologists, $44^{\text {th }}$, Bedford, Pa., Guidebook, p. 18-37.

Harrison, M. J., S. Marshak, and J. H. McBride, 2004, The Lackawanna synclinorium, Pennsylvania; a salt-collapse structure, partially modified by thin-skinned folding: Geological Society of America Bulletin, v. 116, no. 11-12, p. 1499-1514.

Hasson, K. O. and J. M. Dennison, 1988, Devonian shale lithostratigraphy, central Appalachians, U.S.A: Devonian of the world; proceedings of the Second international symposium on the Devonian System; Volume II, Sedimentation, Memoir - Canadian Society of Petroleum Geologists, v. 14, p. 157-177.

Jordan, T.E., 1981, Thrust loads and foreland basin evolution, Cretaceous, western United States: AAPG Bull., v. 65, p. 2506-2520.

Kissling, Don, and Moshier, Stephen O., 1981, "The subsurface Onondaga Limestone; stratigraphy, facies and paleogeography: Guidebook for field trips in southcentral New York; New York State Geological Association, $53^{\text {rd }}$ annual meeting, 18-20 September, p. 279-280.

Lash, Gary G., and Terry Engelder, 2009, The Middle Devonian Marcellus Shale - a Record of Eustacy and Basin Dynamics. Search and Discovery Article 30104 (2009). Web. 27 Jan. 2010. 
Linsley, D.M., 1991, Coarsening- up cycles and stratigraphy of the upper part of the Marcellus and the Skaneateles Formation in central New York; Dynamic stratigraphy and depositional environments of the Hamilton Group (Middle Devonian) in New York State, Part II: Bulletin - New York State Museum (1976), v. 469, p. 75-92.

Macquaker, J., McIlroy, D., Davies, S. J., Keller, M. A., Not Anoxia! How Do You Preserve Organic Matter Then? AAPG Annual Convention and Exhibition, Denver, Colorado, June 7-10, 2009.

Moores, Eldridge M. and Twiss, Robert J., 1995, Tectonics: New York, W. H. Freeman and Company, p. 364-365.

"Natural Gas Weekly Update." U.S. Energy Information Administration - EIA Independent Statistics and Analysis. U.S. Energy Information Administration, 09 Sept. 2010. Web. <http://www.eia.doe.gov/oog/info/ngw/ngupdate.asp>.

Prave, A.R., and Duke, W.L., 1991, Sedimentology and sequence stratigraphic framework of the Middle Devonian Mahantango Formation in central Pennsylvania; Geologic evolution of the Eastern United States; field trip guidebook NE-SE GS A 1991: Guidebook (Virginia Museum of Natural History), v. 2, p. 207-228.

Price, R.A., and Mounjoy, E.W., 1971, The Cordilleran foreland thrust and fold belt in the southern Canadian Rockies (abst.): Geol Soc. America Abs. with Prog., v. 3, p. 404405.

Rast, Nicholas, 1989, The Evolution of the Appalachian Chain, The Geology of North America-An Overview, Volume A, p. 323-344.

Rast, N., Skehan, J.W., 1993, Mid-Paleozoic orogenes is in the North Atlantic. The Acadian orogeny, in Roy D.C. and Skehan, J.W. (Eds.): The Acadian Orogeny: Recent Studies in New England, Maritime Canada, and the Autochthonous Foreland. - Geol. Soc. Amer. Spec. Pap. 275:1-25.

Rickard, L.V., 1975, Correlation of the Silurian and Devonian rocks in New York State, New York State Museum and Science Service Map and Chart Series 24, 16p.

Roden, Mary K., Randall R. Parrish, and Donald S. Miller. "The Absolute Age of the Eifelian Tioga Ash Bed, Pennsylvania." The Journal of Geology 98.2 (1990): 282-85. Print.

Roen, J.B., and Hosterman, J.W., 1982, Misuse of the term "bentonite" for ash beds of Devonian age in the Appalachian basin, Geological Society of America Bulletin, v. 93, p. 921-925. 
Schmoker, J.W., 1981, Determination of organic-matter content of Appalachian Devonian shales from gamma-ray logs: AAPG Bulletin, v. 65, p. 1285-1298.

Schwietering, J.F., 1981, Occurrence of oil and gas in Devonian shales and equivalents in West Virginia; final report: Report DOE/ET/12130-T13.

Swezey, C. S., 2002, Regional stratigraphy and petroleum systems of the Appalachian basin, North America: Geologic Investigations Series - U.S.Geological Survey, v. I-2768.

West Virginia Geological and Economic Survey (WVGES). "Trenton Black River Project Data Resources." 11 Oct. 2006.

<http://www.wvgs.wvnet.edu/www/tbr/resources.asp>. 30 June 2010.

Way, J.H., and Smith, R.C., 1985, Tioga ash zone: 6 or more ash beds in the Valley and Rid ge or Pennsylvania [abs.], Geological Society of America Abstracts with Programs, v. 17, no. 1, p. 68 .

Woodrow, D.L., Fletcher, F.W., and Ahrnsbrak, W.F., 1973, Paleogeography and paleoclimate at the deposition sites of the Devonian Catskill and Old Red facies, Geological Society of America Bulletin, v. 84, p. 3051-3063.

Woodrow, D.L., Dennison, J.M., Ettensohn, F.R., Sevon, W.T., and Kirchgasser, W.T., 1988, Middle and Upper Devonian stratigraphy and paleontology of the central and southern Appalachians and eastern Midcontinent, U.S.A; Devonian of the world; proceedings of the Second international symposium on the Devonian System; Volume I, Regional syntheses: Memoir - Canadian Society of Petroleum Geologists, v. 14, p. 277 301. 